

\section{Vega del Guadalquivir: un territorio marcado por el río}

Esta sección ha sido elaborada, además de los firmantes, gracias a la colaboración de Aniceto Delgado Méndez, Isabel Durán Salado, Silvia Fernández Cacho, Luisa Fernanda de Juan Santos, Valle Muñoz Cruz, Lorena Ortiz Lozano, Carmen Pizarro Moreno, David Villalón Torres
La vega del Guadalquivir, discurriendo entre la sierra y la campiña, unas veces más próximas que otras, según la trayectoria del río, conforma un territorio cuya imagen paisajistica se percibe uniforme, sin fragmentar, y constituye un pasillo de comunicaciones que se ha consolidado con infraestructuras viarias y ferroviarias recientemente mejoradas con redes de alta capacidad. Su apariencia de territorio rico en cultivos no desmerece otra cara netamente urbana compuesta por ciudades ribereñas que se han ido conformando en sucesivas etapas históricas y que, salvo excepciones, no han proyectado una fachada fluvial, que ahora intentan suplir con soluciones que mantengan su relación con el río. El carácter constituyente que tiene el río Guadalquivir para el conjunto del territorio andaluz, lleva a establecer algunas directrices para lograr un tratamiento integral del mismo, particularmente en sus aspectos paisajísticos y patrimoniales. Estas cuestiones, entre otras muchas, son tratadas en la sección.






\section{El Guadalquivir, patrimonio territorial andaluz}

Gonzalo Acosta Bono,

geógrafo-urbanista

El Guadalquivir y sus tierras ribereñas constituyen una de las representaciones más arraigadas en el imaginario colectivo andaluz, siendo sus paisajes evocados desde la antigüedad por geógrafos, viajeros, pintores, poetas y escritores. Textos como el de Estrabón definen con claridad y vigencia el núcleo esencial de este territorio. A modo de palabras claves, dicha descripción contiene todas las características que definen la vega desde los primeros tiempos: el "río", resaltado por sus condiciones para la navegación de la época, y sus "arboledas"; las "tierras cultivadas con esmero"; Hispalis y Corduba como principales ciudades de referencia; la sierra como telón de fondo "aproximándose a él unas veces más, otras menos", y por la otra margen, "grande y elevada Ilanura". Cualquier otra descripción abundará invariablemente en estos elementos.

La estabilidad de esta imagen no sólo ha llegado hasta nuestros días, probablemente el propio Estrabón vino a reconocer un territorio que ya ofrecía estas caracteristicas por su larga trayectoria de ocupación humana. Durante el Neolítico y la Edad del Cobre todavía no era demasiado densa, privilegiándose en esta época para los asentamientos las laderas que flanquean la vega; pero a partir de la Edad del Bronce se produjo una intensificación de la ocupación de la vega y del aprovechamiento de sus recursos, conformándose por las civilizaciones tartésica e ibero-turdetana una potente red de oppida, posteriormente romanizada y mejor articulada a través de la Via Augusta, espina dorsal de las comunicaciones del sur peninsular.

Esta estabilidad no puede asociarse a un cierto estancamiento en la construcción del territorio si no, por el contrario, pese a las grandes transformaciones operadas en él, a la constante profundización de dichos factores. El periodo islámico recoge la herencia de siglos anteriores realizando aportaciones muy significativas tanto en una cultura del agua materializada en infraestructuras para su mejor aprovechamiento y su aplicación a la horticultura y fruticultura, como en la red urbana reforzada por la gran capacidad de organización espacial, jerarquía y funcionalidad. El posterior devenir cristiano no fue diferente para las ciudades de la vega, diluida ya su función militar en el marco de la repoblación y señorialización castellana, y más revalorizada por la función de redistribución de productos incluso a gran escala a través del puerto de Sevilla. El último episodio significativo de este proceso, además de la propia evolución de ciudades y actividades económicas, es la reciente política de colonización que ha permitido la implantación de nuevos núcleos de población para intensificar la explotación agrícola, para la cual también se han construido importantes infraestructuras hidráulicas, además de para la propia regulación del río.

En este texto hay un aspecto que no puede pasar desapercibido, es el propio encuadre de la imagen descrita. No se limita a la propia vega sino que, fiel a la percepción real de un escenario cualquiera, incluye las referencias a los contornos que la enmarcan, resaltando por contraste sus propias caracteristicas internas. A izquierda y derecha se extienden la sierra y la campiña, aproximándose unas veces más y otras menos según la propia trayectoria del río, en cuyo discurrir ha ido conformando la vega propiamente dicha (esos ricos suelos aluviales), siendo testigo de las derivas de su cauce los meandros actuales y otros que han dejado una huella reconocible. No es una cuestión menor, la imagen paisajística se genera a partir de una percepción integrada de lo que se ofrece a la vista, sin fragmentar o descomponer artificialmente lo que en ella se contiene. Son los riesgos o las limitaciones de la "cartografia de paisajes" que toma como perspectiva analítica la identificación de rasgos homogéneos, aunque en la experiencia paisajística no se produce tal descomposición. En el caso de la vega se hace especialmente evidente por su disposición lineal, y se ve reforzada por las privilegiadas vistas panorámicas que ofrecen las alturas aledañas para observarla, e inevitablemente el telón de fondo de las elevaciones en la ribera contraria.

Una segunda consideración sobre la percepción dominante de la vega es que ésta se tiene frecuentemente desde el desplazamiento, reforzado por su carácter lineal y porque desde tiempos remotos este territorio se ha conformado como pasillo de comunicaciones. Prácticamente quedó formalizado durante el 

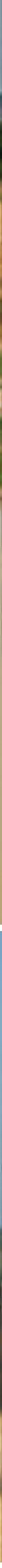

Lora del Río, Sevilla (arriba). Torre de la Calahorra, Córdoba (abajo izquierda). Puente de hierro en Villa del Río (Córdoba) (abajo derecha). Fotos: Juan Carlos Cazalla, IAPH

periodo romano con la Vía Augusta, que todavía puede reconocerse en la toponimia de actuales vías y caminos vecinales (camino viejo, camino romano...), aunque con posterioridad otros factores contribuyeron a reforzarla, como el denso tejido de vías pecuarias que bajan desde la sierra, de la que quizás la más importante sea la cañada Real Soriana. La imagen legada es la del camino, la de un recorrido que siguiendo el curso del río se ha consolidado con infraestructuras viarias y ferroviarias, las convencionales y más recientemente las de alta capacidad. Particularmente la N-IV (A-4), que como principal arteria de la región trasciende al ámbito de la vega al conectarla con el resto de la península (Cádiz-Madrid); pero tiene también una gran importancia la carretera A-431 entre Alcalá del Río y Córdoba por su papel en la articulación interna de la vega. Cuando algunas de estas vías suben por las elevaciones aledañas, nos encontramos en un observatorio perfecto, desde donde la naturaleza de la vega adquiere aún más claridad y la imagen descrita por Estrabón se comprende en toda su dimensión, y también que otros viajeros y escritores se hayan referido invariablemente a estos mismos componentes. Desde el movimiento las perspectivas generadas son infinitas, los planos largos que facilitan la fijación de imágenes de conjunto, más estables, pero también 


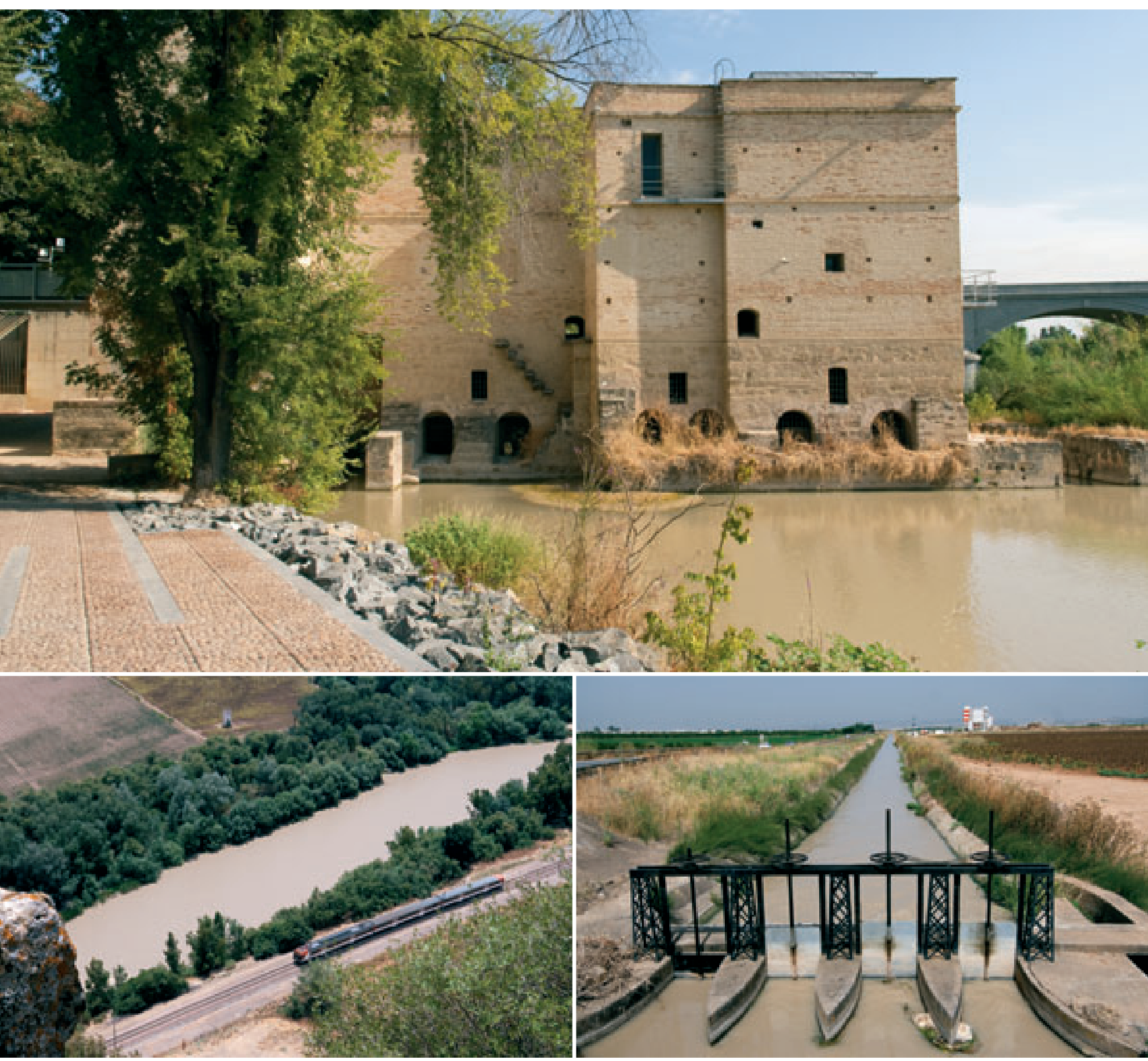

Molino de la Alegría (Córdoba), sede del Museo de Paleobotánica (arriba). Río y trazado del ferrocarril desde el castillo de Almodóvar del Río (Córdoba) (abajo izquierda) Canal de regadío del Bajo Guadalquivir a su paso por Tocina (Sevilla) (abajo derecha). Fotos: Juan Carlos Cazalla, IAPH

los planos medios y cortos que permiten percibir detalles de cuantos elementos conforman la escena de la vega (caserios, arboledas y toda la variedad de cultivos: naranjo, algodón, remolacha, girasol, forrajeras...).

La imagen dominante de un territorio rico en cultivos no desmerece, sin embargo, otra netamente urbana que se deriva de las abundantes ciudades ribereñas que se ha ido conformando en sucesivas etapas históricas. La temprana urbanización sigue el eje del río, factor privilegiado para el asentamiento poblacional, aunque la naturaleza del río impuso la prudencia por los riesgos
La imagen paisajística no se limita a la propia vega, sino que incluye las referencias a los contornos que la enmarcan, resaltando por contraste sus propias características internas 


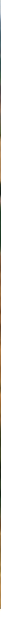

Paisaje de la vega desde el castillo de Almodóvar del Río (Córdoba). Foto: Juan Carlos Cazalla, IAPH

de sus crecidas; sus emplazamientos en las pequeñas elevaciones (especialmente en la margen derecha), o bien a una cierta distancia del cauce fueron los antídotos para resistir mejor las fuertes avenidas, y ha determinado las pautas de sus crecimientos. En las fundaciones de los núcleos urbanos tuvo un peso decisivo la función defensiva en el esquema militar medieval. Esta organización es apreciable en el poblamiento de la vega norte de Sevilla (Cantillana, Brenes o Tocina, con origen en alquerias y otros asentamientos rurales andalusies), o en las proximidades de Córdoba (Posadas, Palma del Río o El Carpio, y Almodóvar como punto estratégico de la defensa militar). Otros núcleos en los límites de las respectivas demarcaciones tienen también una vocación de control militar entre las entidades políticas. Así, Lora, Setefilla y Peñaflor entre los territorios sevillano y cordobés; Montoro, Arjona y Lopera (algo más retiradas de la propia Vega) entre el reino cordobés y el jiennense.

Salvo excepciones, son ciudades que no han proyectado una fachada fluvial, más bien traseras marginales que sólo muy recientemente, con las obras de regulación general del río, buscan algunas soluciones para mantener una relación con el río más próxima y cuidada procurando integrar el río en el espacio urbano mediante un tratamiento de espacio público que le proporcione un escenario e imagen urbana más reconocible por su singularidad y calidad. La imagen moderna del territorio construido se corresponde, no obstante, con modelos arquitectónicos, formas urbanas y materiales cada vez más homogéneos y repetitivos.

El río es también el elemento determinante en los trazados de las redes viarias, y cuando hay que cruzarlo para conectar los territorios campiñeses y serranos, el puente antecede a la vía y recuerda a los antiguos vados. Algunos se conservan desde la época romana (Córdoba, Villa del Río y Andújar) y hasta hace poco han soportado el tráfico de la N-IV, lo que atestigua la calidad de su fábrica. Es en estos momentos del recorrido cuando se nos ofrece a la vista toda la magnitud del río, la dimensión de su cauce o la vegetación de sus riberas (álamos blancos, sauces, olmos...), y también se puede imaginar que en otras épocas fue vía de navegación, o por el que se transportaban los troncos desde la Sierra de Segura a los astilleros sevillanos. El rio ha sido desde siempre objeto de numerosas intervenciones para domesticarlo y para aprovechar sus recursos. De estas intervenciones quedan registros e hitos característicos y valiosos desde un punto de vista patrimonial (estructuras como norias, molinos, embarcaderos, obras de defensa frente a las avenidas...), pero salvo honrosas experiencias locales, falta un tratamiento global y potente sobre todos sus valores. Hay que celebrar la reciente aparición de El Río Guadalquivir por tratarse de una gran obra de sintesis que supone un re-conocimiento y pone de relieve los muchos valores que encierra.

El Plan de Ordenación del Territorio de Andalucía establece algunas directrices relacionadas con el objetivo de lograr un tratamiento integral del río Guadalquivir, particularmente en sus aspectos paisajísticos y patrimoniales. Por una parte, dado el carácter constituyente que tiene el Guadalquivir para el conjunto del territorio andaluz (formado en un 90\% por su cuenca hidrográfica y por la que se relacionan las grandes unidades territoriales: los ámbitos serranos -Sierra Morena y serranías béticas-, y éstas con los litorales atlántico y mediterráneo), es pieza clave en el proceso de su construcción y vertebración regional. Por otra parte, en la vega propiamente dicha, formada por suelos de gran calidad y valor agrícola, se está produciendo un potente entramado de infraestructuras (de transportes e hidráulicas) y sistemas urbanos, que la somete a una fuerte presión transformadora descuidando sus valores patrimoniales. La vega, por su disposición lineal siguiendo el río, es en si mismo un itinerario temático que deberá adquirir un papel relevante en la estrategia para poner en valor toda la riqueza y significados del Guadalquivir, verdadero patrimonio territorial de Andalucía que requiere ser abordado de manera integral y ambiciosa. El momento es oportuno porque, tras la constante reivindicación de las competencias para su gestión por la Comunidad Autónoma, estamos casi estrenando sus recientes transferencias. 


\section{Sobre el libro El Río Guadalquivir}

El escritor inglés Paul Gwynne, en su obra The Guadalquivir (2006, Sevilla: Ed. Renacimiento. Centro de Estudios Andaluces), escribía que un río determina el destino de un pueblo con más fuerza que ningún otro tipo de accidente sobre la superficie de la tierra, y definía al Guadalquivir como un rio madre que ha engendrado y amamantado a un pueblo, nodriza de una historia, de una lengua y de un arte. Otros autores, menos líricos, como Pierre Vilar, hablan de los ríos, más allá de su carácter simbólico, como los portadores del recurso natural por excelencia, el agua, como elemento necesario para la vida, factor de riqueza, medio de transporte, fuerza energética, añadiendo que la linealidad y el flujo de las aguas de los ríos confieren unidad a muy diversos elementos del paisaje que sin su presencia resultarían diferentes e inconexos.

Un río, como de los que escribe Paul Gwinne y Pierre Vilar, el Guadalquivir, ha sido origen físico de Andalucia, de su territorio, modelador de su paisaje y de su clima, causa y motivo de sus venturas y avatares históricos, alfa y omega de su existencia. Al estudio y divulgación de este río, está dedicada la publicación que ahora comentamos, editada por las consejerías de Obras Públicas y Medio Ambiente de la Junta de Andalucía y por la Confederación Hidrográfica del Guadalquivir del Ministerio de Medio Ambiente. La salida de la edición (junio de 2008) coincidió con la fecha del traspaso de la titularidad y gestión del Guadalquivir a la Junta de Andalucía.

Como responsable de su edición quiero resaltar el carácter colectivo y multidisciplinar de ésta, obra de muchos autores, que ha intentado abordar la compleja realidad del Guadalquivir, y su historia, a través de múltiples y variadas miradas. El libro que hoy glosamos ha sido realizado gracias a la aportación de diversos profesionales, procedentes de diferentes disciplinas y actividades, que se han acercado a interpretar lo que ha sido el Guadalquivir en el pasado, e intentar describir lo que es en la actualidad, desde distintas disciplinas y variadas ópticas.

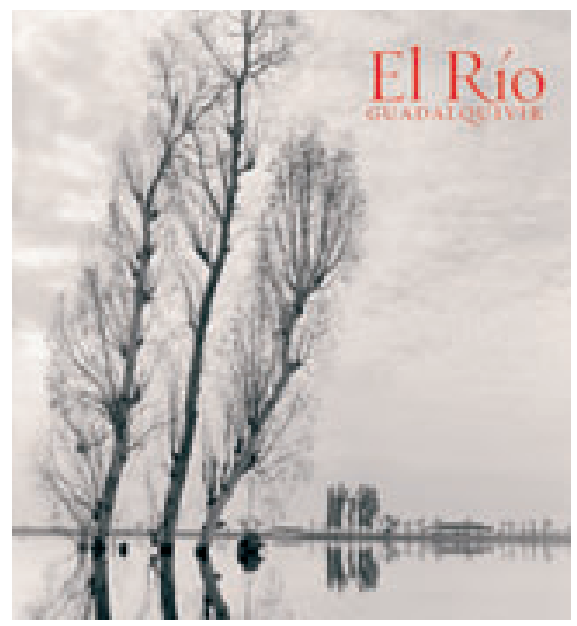

Cubierta del libro El Río Guadalquivir, sobre foto de Manuel de Arcos
La edición está planteada como una obra de carácter científico y divulgativo, cuyos textos siempre cuentan con el apoyo de un importante material gráfico que permita una doble lectura, la de los textos y la de las ilustraciones. En la obra han participado, historiadores, biólogos, geógrafos, ingenieros, documentalistas, diseñadores gráficos, fotógrafos, editores, informáticos, urbanistas, arquitectos, impresores, etcétera.

Un largo número de profesionales que durante algo más de dos años han puesto sus esfuerzos en común para llevar a cabo este proyecto, compendio de diferentes visiones sobre el Guadalquivir, desde diferentes ángulos.

El paisaje, la naturaleza, la historia, el urbanismo, las actividades humanas, el arte y la literatura han sido los ejes de este recorrido.

Desde Tartesos al Plan General de Ordenación Urbana de Sevilla, de las maderas de la Sierra de Segura al caviar de Coria del Río, de los regadíos a los poemas de Lorca y Antonio Machado, del Guadaira al Genil, se ha intentado realizar una amplia sintesis del río, considerado como eje de lo que algunos autores han llamado civilización hidráulica, cardo o gozne de todo lo importante y trascendente que ha ocurrido en Andalucía a lo largo de los tiempos.

El importante aparato gráfico que acompaña la obra, ha requerido de un exhaustivo trabajo de documentación, realizado por un amplio equipo de profesionales, que ha llevado a cabo una amplia investigación por infinidad de archivos, bibliotecas, centros de documentación, museos, colecciones particulares, tanto españolas como extranjeras. Esta labor ha permitido elaborar un corpus iconográfico de gran valor documental. Pensamos que es una obra sintesis de muchas aportaciones y muchos y variados esfuerzos, que representa una puesta al día de los múltiples estudios que desde diferentes perspectivas se están realizando sobre el Guadalquivir.

También se deben destacar los reportajes especificos, encargados a reconocidos profesionales de la fotografía, lo que aporta a la obra un valor añadido, ya que gran parte de este material tiene un carácter inédito. También se incluye en la obra un homenaje gráfico al fotógrafo sevillano Atín Aya, fallecido durante la edición de la obra.

La mayor parte de los autores de los textos que conforman el sumario proceden del ámbito universitario, y dentro de éste, un buen número de ellos procede de las universidades de Sevilla, Cádiz, Córdoba, Granada y Jaén. Este hecho nos confirma, aparte de la vitalidad y buen hacer de las universidades andaluzas, que el Guadalquivir es objeto prioritario de estudio dentro de ellas. Otro buen número de autores procede de otros ámbitos, como son la propia Junta de Andalucía, la Confederación Hidrográfica del Guadalquivir, o el Consejo Superior de Investigaciones Científicas y su homólogo, el CNRS francés. También, y sin desmerecer ni un ápice, los hay que proceden del ámbito privado.



El río en Montoro (Córdoba). Foto: José Manuel Navia

Pensamos que este esfuerzo realizado en común, puede y debe tener continuidad en otros proyectos, continuadores de la tarea iniciada, que no es otra que la de dar a conocer, a través de diferentes miradas y disciplinas, las múltiples facetas desde las que se puede abordar la realidad del Guadalquivir, realidad de una complejidad y una riqueza apabullante, y a la que nos debemos acercar con nuevas miradas.

Desde nuestra perspectiva personal, los retos son amplios y complejos. Asumimos con fuerza e ilusión el compromiso de seguir con nuevos proyectos editoriales que continúen éste ya iniciado, y participar en otros, relacionados con el amplio abanico de visiones que se abren con el traspaso de competencias del Guadalquivir. Sin exagerar, se inicia una nueva época, en la que es necesario acercar y dar a conocer esa realidad tan espléndida y rica, y que en muchas ocasiones aparece escondida y por tanto desconocida.

Quiero adelantar que en este momento, la Junta de Andalucía (por medio de las consejerías de Medio Ambiente, Obras Públicas y Transportes, Vivienda y Urbanismo, Turismo, Comercio y Deportes y Cultura) está poniendo en marcha una colección de libros sobre el Río Guadalquivir que, siguiendo el modelo editorial, tanto en la forma como en el contenido, del que ahora comentamos, abordaria la realidad del río en cinco volúmenes, dedicados a realizar un recorrido editorial por todo el Guadalquivir, desde su desembocadura hasta el nacimiento, siguiendo los limites de las provincias que atraviesa.

Se ha comenzado ya con la edición del volumen dedicado a Sanlúcar de Barrameda, cuyo estudio abarcaría desde esta ciudad a Trebujena. El segundo tendría como eje a Sevilla, desde Lebrija a Alcalá del Río, el tercero a Córdoba, desde Palma del Río a Villa del Río, el cuarto a Jaén, desde Marmolejo a Cazorla, y el quinto estaría dedicado a Granada, el Genil y la orilla izquierda. Esperamos que este proyecto pueda llegar a buen puerto y sirva para tener una obra de referencia que sirva para conocer el pasado del Guadalquivir y también para poner sobre la mesa los ingentes y variados problemas que éste tiene.

\section{Javier Rubiales Torrejón}

Licenciado en Historia y editor 


\section{El Guadalquivir y su imagen en el siglo XIX: la construcción de un paisaje (1830-1862)}

Francisco Javier Rodriguez Barberán, Dpto. Historia, Teoría y Composición Arquitectónicas, Universidad de Sevilla
Escribe Antoine de Latour en 1846, cuando inicia su periplo por Andalucía como parte del séquito del duque de Montpensier: "Donde no había cultivos, las flores se habían apoderado de la tierra para dibujar admirables tapices. ... Así era la ruta encantada por la que bajábamos a las orillas del Guadalquivir. El río que da vida a Andalucía se nos mostró, por fin, poco antes de llegar a Andújar. Sus aguas, un tanto turbias, tenían el tinte rosado de las del Nilo: una armonía más en el paisaje." (LATOUR, 2008: 21). Contra lo que parece ser una costumbre extendida en los libros de viajes por la España del XIX, Latour no recurre a ninguna artimaña: él conoce Egipto, país que había recorrido apenas un año antes, y la comparación, aunque subjetiva por su carácter evocador, responde en principio a la propia experiencia.

Si he elegido el texto del autor francés para arrancar este itinerario cultural en torno a la imagen del Guadalquivir es porque alberga muchos elementos de interés, que empiezan por la propia equidistancia entre la dimensión literaria y el registro de la realidad que los Études sur l'Espagne, Séville et l'Andalousie -título de la obra donde se incluye, publicada en 1855- transmiten de modo habitual. Este término medio es el que también permite explicar el sentido de la acotación cronológica que aparece al frente de este artículo: Latour se inserta dentro de un periodo crucial para la visión de Andalucia en la cultura occidental, y que se ha vinculado en numerosas ocasiones al adjetivo "romántico" (AA.W, 1985). Sin embargo, son cada vez mayores los matices que conviene establecer acerca de este vínculo entre el movimiento estético y de mentalidades que supone el Romanticismo y el colectivo de los viajeros que durante varias décadas del siglo XIX recorren Andalucía para asomarse a la misma, en muchas ocasiones, como a un "Oriente cercano y confortable" (RODRÍGUEZ BARBERÁN et ál., 2007: 113). Las fechas elegidas hacen alusión a dos hechos concretos, que tienen además el río como referencia común: en noviembre de 1830 llegaba a Sevilla a bordo de un vapor, y tras hacer escala en Gibraltar y Cádiz, Richard Ford; en 1862 eran el barón Charles Davillier y el ilustrador Gustave Doré quienes, tras recorrer las provincias de Granada, Málaga y Cádiz, tomaron el barco en Bonanza para remontar el Guadalquivir. Ford era en aquel mo- mento un heredero de la mentalidad ilustrada que se adentra en un territorio que le fascina y le enerva a partes iguales (RODRíGUEZ BARBERÁN et ál., 2007: 111). Por su parte, Davillier y Doré estaban consolidando, a través de la palabra y la imagen respectivamente, un universo en el que la cultura quedaba oscurecida por los tópicos, condenando toda visión a una permanente búsqueda de la charanga y la pandereta. En ambos casos, el resultado del periplo andaluz serán dos libros de extraordinaria repercusión, y es que tanto el Handbook for Travellers in Spain de Ford, publicado en Inglaterra en 1844 (FORD, 2008), como el Voyage en Espagne de Davillier y Doré, editado ya por entregas en el mismo año de 1862 (DAVILLIER, 1988), alcanzaron un gran éxito en Europa. Sus visiones, sin estar enfrentadas, presentan notables diferencias, y creo que pueden ser invocadas como extremos de una imagen de España, pero sobre todo de Andalucía, sobre la que ahora vamos a reflexionar. Para ello se hace necesario volver al texto de Latour.

Cuando el viajero francés relata su primera visión del Guadalquivir cede por completo a la atracción del lugar, hablándonos de tapices de flores y de una "ruta encantada"; de hecho, no hay mejor refuerzo para ello que el paralelismo apuntado entre nuestra región y Egipto, como parte aquí de ese extenso Oriente -en lo geográfico pero también en lo cultural-que tanto atrajo al pensamiento europeo desde mediados del siglo XVIII y hasta bien avanzado el XIX (RODINSON, 1989; MÉNDEZ RODRÍGUEZ, 2008: 15-57). Hay, sin embargo, otro hecho importante: la aparición, al final del fragmento, de un término esencial: paisaje. El texto nos ofrece de este modo una lectura más amplia: Latour construye con la palabra, y ante los lectores de sus Études..., un paisaje en el que el río se convierte en elemento fundamental. Como se ha señalado en diversos estudios sobre la imagen de Andalucia (LACOMBA, 2007: 24), la posición del Guadalquivir en la propia geografía se traslada a su importancia en la formalización del paisaje andaluz como hecho contemporáneo. Bien es cierto que debe aceptarse una excepción a esta regla: me estoy refiriendo al corpus iconográfico vinculado a Granada y a la Alhambra, que seria junto al de las grandes ciudades ribereñas -Córdoba y Sevilla- el otro núcleo en torno al cual se define la 


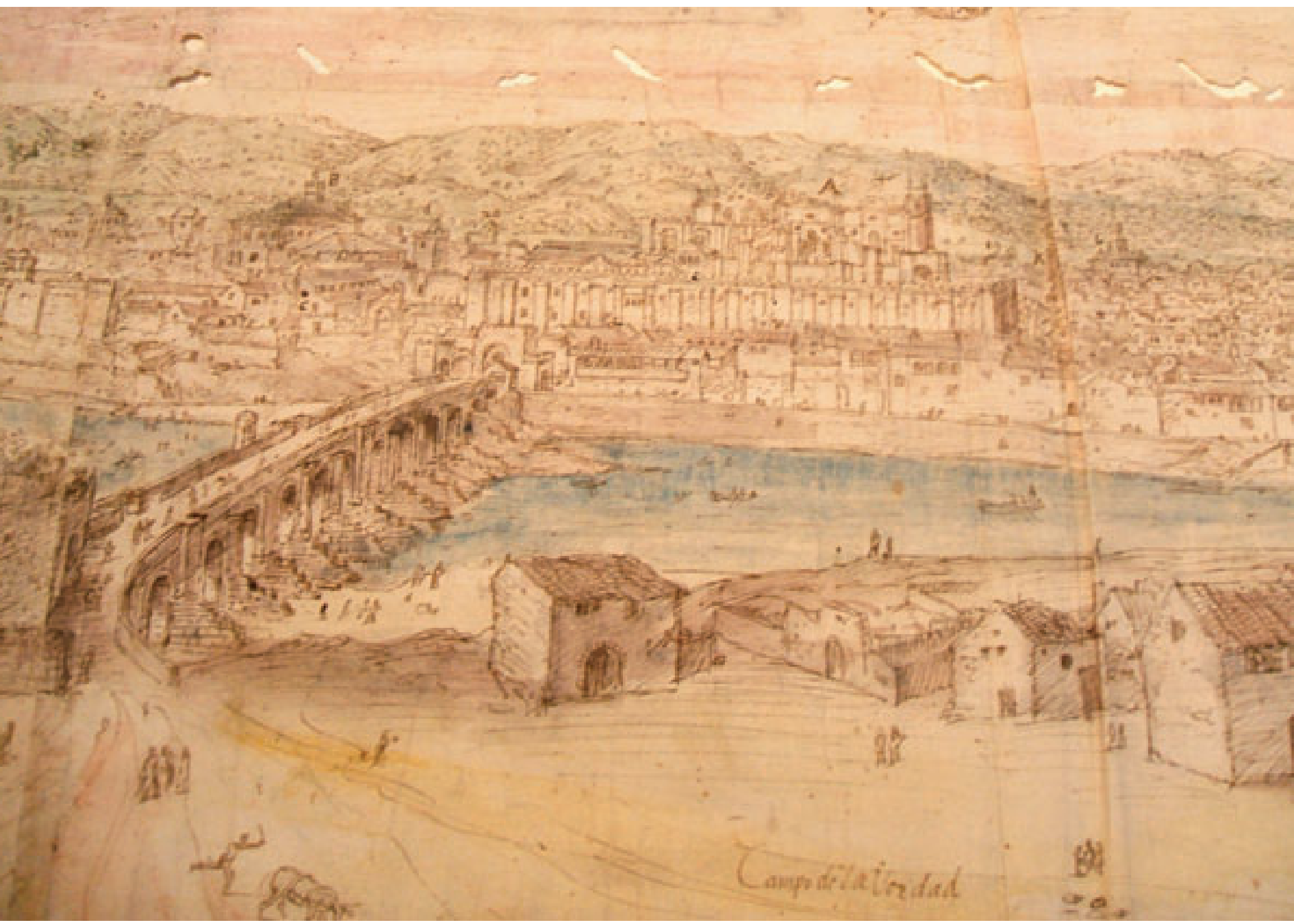

Vista de Córdoba (1567). Anton van Wyngaerde. Detalle. Victoria \& Albert Museum, Londres Foto: Javier Rodríguez Barberán

proyección exterior de Andalucía. Sin embargo, esto ya había venido ocurriendo desde principios de la Edad Moderna: cualquier reflexión en torno a las vistas de las ciudades y los territorios de Andalucia, aun aceptando la diversidad de las representaciones, termina por mostrar con claridad que Granada (GÁMIZ, 2008), Córdoba (COSANO, 1999) y Sevilla (SANTIAGO et ál., 1988; SERRERA et ál., 1989), monopolizan prácticamente la imagen que del sur de la Península lbérica se tiene en el continente.

Esta incursión en el pasado permite invocar el precedente de los siglos XVI y XVII: en las vistas de Sevilla y de Córdoba de este periodo, realizadas por autores como Wyngaerde, Brambilla o Hoefnagel, el Guadalquivir es siempre protagonista al aparecer en primer plano. Córdoba se nos muestra, en esencia, como una ciudad vista desde la margen opuesta del río, con el puente romano y la mezquita-catedral como referencias; Sevilla, por su parte, es la urbe que se vislumbra desde el Aljarafe, con el río ante ella surcado por innumerables barcos y la agitación del puerto de las Indias. Rara vez se modifican estos puntos de vista, y como consecuencia de ello, si vamos más allá de las fronteras peninsulares, para cualquier europeo culto de la era del Humanismo, ambas poblaciones serían, jugando con la frase que Herodoto aplicó a Egipto, "un don del Guadalquivir".

Con estos antecedentes no es extraño que el río desempeñe durante el siglo XIX un papel esencial a la hora de que Andalucia se convierta, ante los ojos de los viajeros continentales y de quienes se enfrentan a sus textos o a sus grabados -por citar las dos herramientas de difusión más extendidas, y a las que se añadirá la fotografía a partir de 1850-, en un territorio propicio para la ensoñación. Siendo extraordinaria la densidad histórica de los acontecimientos vinculados al Guadalquivir, lo más atractivo para la mayoría de los ingleses, franceses y visitantes de otras muchas nacionalidades, parece ser la posibilidad de convertir al río grande en un escenario para las fantasías de la época. Sin embargo, no conviene ceder a la tentación simplificadora de un único río, un río teñido de exotismo y en torno al cual se mueven los personajes del imaginario romántico. Ello significaría renunciar a la pluralidad de registros que cualquier análisis riguroso desvela: la naturaleza del propio siglo así lo demanda, y por ello conviene 


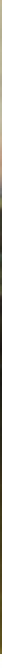

Vista de Sevilla con el Puente de Triana. Manuel Barrón. Palacio Real, Madrid. Fuente: RODRÍGUEZ BARBERÁN et ál., 2007

fuerza de su propia educación y de la costumbre -los carnés de viaje, tan importantes en el mundo del Grand Tour por Europa-, pero también ante el obstáculo insalvable de la ausencia de un medio mecánico de reproducción que está a sólo unos pocos años vista de su irrupción, la fotografía (RODRíGUEZ BARBERÁN et ál., 2007: 116-121). Los dibujos se convierten así en fuente primaria para el libro que elaborará años más tarde, y con ellos el texto se impregnará, como señalan F. Márquez y J. Cascales, de una visión del paisaje muy precisa y estructurada (RODRÍGUEZ BARBERÁN et ál., 2007: 149-165). Es en este contexto donde se insertan las vistas de los alrededores de Sevilla y de sus espacios extramuros que tienen al Guadalquivir como protagonista: de los más de cien dibujos y apuntes de Ford dedicados a la capital andaluza, son al menos quince los que muestran la importancia del río para comprender la propia ciudad y su entorno. Las vistas desde el Aljarafe o desde el meandro, así como las imágenes del cauce cercanas a las murallas, con la Torre del Oro como gran referencia, revelan un carácter poco dado a la ensoñación. Es cierto que el autor se recrea en la belleza del paisaje, pero la dimensión de éste atiende a dos grandes referencias: el desarrollo de la destreza artística y

L la elaboración de una memoria en papel de las sensaciones que trasladaría con el tiempo a su Manual.

No deja de ser curioso que exactamente por esos mismos años un pintor también británico, el escocés David Roberts, realice otra aportación esencial para la imagen de la España del XIX, y con un perfil que complementa a la perfección el de Richard Ford. Entre 1832 y 1833, Roberts recorre la Península (GIMÉNEZ, 2002) elaborando una serie de dibujos y óleos con un objetivo concreto: alcanzar el reconocimiento como artista especializado en el género del paisaje y convertir ese conjunto de obras en la fuente de inspiración de series de grabados. Obsérvese la complementariedad antes señalada: aunque Roberts escribe un interesante conjunto de cartas desde España, su visión se transmite al gran público a través de las estampas que ilustrarán las guías y los libros de viajes de otros autores -curiosamente no el Manual de Ford, que se edita sin ilustraciones- a partir de 1835. Por otro lado, Roberts no es un aficionado, como Ford, sino que es una persona que hace de la pintura su profesión, y que por tanto participa de las corrientes artísticas del momento. En él sí que se manifiesta con claridad la imagen de España como meca del viajero romántico; y además se trata de una imagen en la que, como en el caso de Ford, Andalucia posee un peso extraordinario. Sin tener que recurrir a la ambientación histórica, los dibujos, acuarelas y óleos de David Roberts -y los grabados que surgen a partir de ellos- poseen siempre un carácter evocador de otros tiempos, y se impregnan de una melancolía que los convierte en expresiones precisas de la mentalidad romántica. De un modo diferente a otro artista inglés que viaja por España también a principios de los años treinta, John Frederick Lewis, Roberts es sobre todo 
paisajista, y así lo plasma en dos auténticas obras maestras: los cuadros del Museo Nacional del Prado La Torre del Oro y El castillo de Alcalá. La atmósfera de ambos lienzos nos muestra el río como un ámbito propicio para que los sentimientos y las emociones se pongan de relieve; de hecho, las dos obras están unidas por las últimas luces del día, y el atardecer se convierte así en un elemento central para construir el propio paisaje. Sin embargo, mientras que en la visión de la Torre del Oro la noche no se manifiesta aún, en la imagen de las riberas del Guadaíra con el castillo al fondo, las sombras poseen ya un gran protagonismo. No creo, sin embargo, que resulte casual el hecho de que la vista de Sevilla se convierta en un reproducidisimo grabado (GIMÉNEZ, 2002: 429), mientras que esto no ocurre con la de Alcalá. La presencia de la Torre del Oro concede a la primera el tono "orientalista" del que carece la lejana vista del castillo, y su carácter resulta además mucho más pintoresco gracias a la galería de tipos que aparecen en ella. De hecho, la imagen sevillana se encuentra muy cerca del espíritu de otras obras de Roberts con el Guadalquivir como tema: éste sería el caso de sus vistas de Córdoba, y de modo muy especial la que realiza desde el paseo de la ribera, con las grandes referencias monumentales -puente romano y mezquita-catedral- al fondo, y un grupo de pescadores, vendedores de loza, majos y majas o simples paseantes en primer plano (COSANO, 1999: 88-89).

Lo comentado sobre Roberts da pie también a otra reflexión, que en cierto modo ya manifestaban los dibujos de Ford, aunque se trataran de una obra sin ánimo de difusión: el río podía ser también considerado por sí mismo, sin tener que atender a su inserción en un contexto urbano. Que el pintor escocés se acerque a la pequeña población de Alcalá de Guadaíra, como también lo hizo el francés Eugène Delacroix en su breve paso por España (LACOMBA, 2007: 42), fortalecía el concepto de un paisaje desligado del componente histórico, para poner el foco en las posibilidades plásticas del mismo. Esto, que resultaba extraño a los autores españoles del momento, permitió no obstante abrir caminos que serian explorados en el futuro. Pensemos, por ejemplo, en el pintor gallego Jenaro Pérez Villaamil, uno de los artistas con los que Roberts tuvo relación (GIMÉNEZ, 2002: 283287) y que ya en 1843 había realizado una obra como El Castillo de Alcalá -hoy en el Museo de Buenos Aires (LACOMBA, 2002: 33-34)-, completamente deudora del artista escocés, y donde el río sirve para una reflexión en la que la dimensión plástica y la de la propia escena están bastante equilibradas. Sin embargo, esto no significaba renunciar a que el Guadalquivir continuara siendo soporte de relatos históricos o de ensoñaciones exóticas como nos muestra un cuadro del mismo Pérez Villaamil, fechado en 1848, y en el que la vista del río y la Torre del Oro sirven de excusa para recrear lo que el propio título de la obra hace explícito: Sevilla en tiempo de los moros (LACOMBA, 2007: 26-27). Con ella se demuestra que nos encontramos ante una fase de tanteo, y también lo flexible de las fronteras entre los géneros del paisaje, de la pintura de historia e incluso del orientalismo, en un autor que recoge las influencias europeas y que las consolida en la plástica española.
Ante estas circunstancias, el paisaje fluvial del Guadalquivir empezaria mostrar otros rostros: ya sea explotando la vertiente pintoresca, ya a través de la búsqueda de nuevos efectos para la pintura, el río comienza a ser representado de un modo distinto, que le confiere más protagonismo. En cierto sentido, la plástica comienza a ir de la mano de lo que ya había ido encontrado lugar en las páginas de los libros. Cuando George Borrow describe la Sevilla de 1839 en su famosa obra La Biblia en España contrapone el interior de la ciudad -repleta de calles sucias y angostas, atestadas de mendigos- con el entorno del río. Habla asi del placer de vagar por sus márgenes, de los "largos senderos umbríos" y de un panorama "de inefable hermosura", que ni siquiera podria representar en toda su belleza "el pincel de Claudio mismo" -se refiere al pintor del clasicismo francés Claudio de Lorena-, para concluir con un elemento que el tópico se encargará de repetir hasta el agotamiento:"... respirando las brisas cargadas con el aroma de los naranjales" (BORROW, 1970: 514-515). Las semejanzas entre lo que Borrow comenta y la "ruta encantada" que nos describirá Antoine Latour algunos años después en el texto ya comentado, son más que evidentes. Para ambos el valor del paisaje no radica en la aparición de monumentos singulares o de ruinas que evocan el pasado; la belleza del mismo reside en una naturaleza esplendorosa, que demanda ser descrita por medio de la palabra o trasladada al lienzo. Comienza así la construcción de una nueva imagen del territorio en la que el Guadalquivir desempeñará un papel muy importante, y que arranca, como ya hemos mencionado, de la deriva costumbrista del Romanticismo para alcanzar un primer hito durante la segunda mitad del siglo con la consolidación del paisaje realista (LACOMBA, 2007: 49-73).

Basta con revisar los repertorios iconográficos realizados sobre las ciudades ribereñas -de especial relevancia es el caso de Sevilla (CALVO, F. et ál., 1991), con el interesante añadido de lo que más adelante se conocerá como la Escuela (paisajista) de Alcalá de Guadaíra (LACOMBA, 2002)- para advertir este cambio, que es en realidad el reflejo de las transformaciones económicas, sociales,

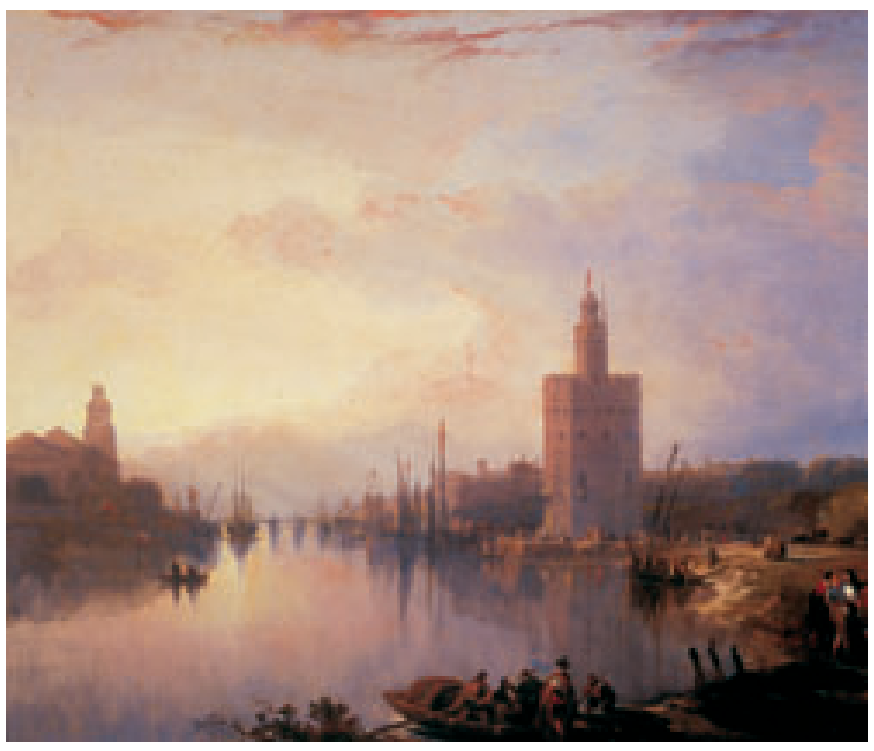

La Torre del Oro. David Roberts. Museo Nacional del Prado, Madrid. Fuente: RODRIGGUZ BARBERÁN et ál., 2007 
culturales y, por ende, urbanas, de la España isabelina. Aunque el sustrato del pintoresquismo no se ha esfumado, ello parece obedecer tanto a la propia formación de los artistas como a las características de la producción pictórica, planteada muy a menudo para un mercado -de viajeros, pero también de clases acomodadas del país- que demanda estas obras por su carácter esencialmente decorativo (MÉNDEZ RODRÍGUEZ, 2008: 73-77). Autores como Andrés Cortés y su extenso taller, o Manuel Barrón (LACOMBA, 2007: 53-58) responderian, durante las décadas de los cincuenta y los sesenta sobre todo, a estos principios. No obstante, un análisis de este periodo pecaría de superficialidad si no se pusieran de relieve otras cuestiones que se hacen presentes en ese momento. Me refiero, sobre todo, a la influencia de la fotografia, que comienza a popularizarse como souvenir para los turistas y como ilustración de publicaciones a partir de 1850. Frente a la destreza manual, el nuevo medio propone una acción mecánica, ligada al desarrollo tecnológico. Precisamente por ello no colisiona con la pintura, sino que se pone, en sentido figurado, al servicio de ésta: el cuaderno de apuntes puede ser sustituido por la cámara, o por el resultado del trabajo del fotógrafo -las colecciones de imágenes en forma de postales-, que se incorpora a las herramientas con las que trabaja el pintor. Además, por su carácter moderno, la fotografía tiende a ofrecer nuevas perspectivas, y a seleccionar otros objetos ante al objetivo, ya que quiere convertirse en un testigo de su tiempo. Que Manuel Barrón, un artista formado en la tradición, ejecute una vista del río en la que el protagonista es un "artefacto sin pasado" (RODRÍGUEZ BARBERÁN, 2008: 47) como el Puente de Isabel II -conocido popularmente como Puente de Triana- sirve para testimoniar a la perfección estos cambios.

Resulta singular la coincidencia de que el año en que se ejecuta esta obra -1862- sea el del mencionado periplo de Davillier y Doré por el Guadalquivir. A los viajeros franceses el río no les cau- sa la impresión que produjo en algunos de sus antecesores: apenas hay un breve apunte histórico y alguna critica a su estrecho cauce (DAVILLIER, 1988: 373-379). No obstante, hay en él algo que les interesa mucho más: Ios toros que aparecen en las dehesas sirven de excusa para trasladarnos, a través de un picador con el que comparten el viaje, al peculiar mundo de las corridas. El espacio del río es, para ellos, el marco sobre el cual superponer los trajes típicos, el ritual de la fiesta y la galería de figuras singulares. El Guadalquivir, por tanto, vuelve a multiplicarse: Io pintoresco convive con el presente retratado con la precisión de la cámara fotográfica, y al mismo tiempo se van sentando las bases para que pueda convertirse en el paisaje realista de los pintores que hallarán en él una versión española de la École de Barbizon. Quizás por ello no resulte contradictorio que alguien aficionado a la pintura y acostumbrado a crear sugerentes imágenes con la palabra, el poeta Gustavo Adolfo Bécquer, vea el río como contrapunto de una ciudad que ya no reconoce. En noviembre de 1862 publica en el periódico El Contemporáneo la leyenda La Venta de los Gatos (BÉCQUER, 2004: 327-335). Bécquer expresa en ella su desencanto ante las transformaciones del paisaje urbano y humano de Sevilla, comparándola con sus recuerdos, indudablemente idealizados. Sus paseos por calles y plazas le llenan de insatisfacción, y sólo el Guadalquivir le ofrece consuelo. Alli, precisamente desde el puente de Isabel II, disfruta de un "magnífico panorama", repleto de "mil detalles ... pintorescos"; admira las márgenes repletas de "jardines, palacios y blancos caseríos", y su mirada se pierde en el cauce, con "los innumerables buques ... que desplegaban al aire los ligeros gallardetes de mil colores". La estampa literaria tiene el aire de las postales coloreadas que empezarán a comercializarse en el último tercio deI XIX, y parece convertirse con ello en tránsito simbólico hacia una idealización del río, pero también de Andalucía, que el siglo XX verá nacer. Pero ése es otro paisaje.

\section{En la web}

\section{GUADALOUIVIR, RÍO DE HISTORIA} www.guadalquivirriodehistoria.es

Organización dedicada a divulgar el patrimonio cultural en torno al río Guadalquivir. El sitio web muestra la ruta "Derroteros del Guadalquivir", sobre el Guadalquivir de los siglos XVI al XVIII. Jornadas y exposiciones son algunos de los recursos disponibles.

\section{ASOCIACIÓN COMARCAL GRAN} VEGA DE SEVILLA

wWw.gvs.es

Este sitio web presenta tanto el Plan Estratégico Gran Vega (2007-2013) como información sobre los municipios que conforman la comarca de la Gran Vega.

\section{CONFEDERACIÓN HIDROGRÁFICA DEL GUADALQUIVIR \\ www.chguadalquivir.es}

En el portal web de este organismo podremos encontrar información exhaustiva sobre la demarcación hidrográfica del río Guadalquivir, datos socioeconómicos, información medioambiental y cartográfica, entre otros recursos de interés.

\section{SCARPIA}

www.scarpia.es

Espacio para la creación contemporánea en el municipio cordobés de El Carpio. En este sitio web se puede encontrar un recorrido por las intervenciones y conferencias realizadas desde el 2002 junto a referencias de webs de los distintos artistas participantes e invitados. Presentación de las últimas jornadas realizadas: Jornadas de Intervención Artística en el Espacio Natural y Urbano.

\section{JARDÍN BOTÁNICO DE CÓRDOBA}

www.jardinbotanicodecordoba.com

El molino de Martos forma parte del patrimonio etnológico y etnobotánico del Jardín botánico de Córdoba. Su sitio web ofrece información histórica, glosario e imágenes del molino así como su relación con el entorno.

\section{CÓRDOBA EN 3D}

martoos.blogspot.com

Animación 3D del molino de Martos así como imágenes históricas es lo que podemos encontrar en este blog.

\section{AYUNTAMIENTO DE PEÑAFLOR (CÓRDOBA)}

www.penaflor.es

La web del Ayuntamiento de Peñaflor ofrece información sobre la historia del municipio, con datos del enclave romano de Celti. 
culturales y, por ende, urbanas, de la España isabelina. Aunque el sustrato del pintoresquismo no se ha esfumado, ello parece obedecer tanto a la propia formación de los artistas como a las características de la producción pictórica, planteada muy a menudo para un mercado -de viajeros, pero también de clases acomodadas del país- que demanda estas obras por su carácter esencialmente decorativo (MÉNDEZ RODRÍGUEZ, 2008: 73-77). Autores como Andrés Cortés y su extenso taller, o Manuel Barrón (LACOMBA, 2007: 53-58) responderian, durante las décadas de los cincuenta y los sesenta sobre todo, a estos principios. No obstante, un análisis de este periodo pecaría de superficialidad si no se pusieran de relieve otras cuestiones que se hacen presentes en ese momento. Me refiero, sobre todo, a la influencia de la fotografia, que comienza a popularizarse como souvenir para los turistas y como ilustración de publicaciones a partir de 1850. Frente a la destreza manual, el nuevo medio propone una acción mecánica, ligada al desarrollo tecnológico. Precisamente por ello no colisiona con la pintura, sino que se pone, en sentido figurado, al servicio de ésta: el cuaderno de apuntes puede ser sustituido por la cámara, o por el resultado del trabajo del fotógrafo -las colecciones de imágenes en forma de postales-, que se incorpora a las herramientas con las que trabaja el pintor. Además, por su carácter moderno, la fotografía tiende a ofrecer nuevas perspectivas, y a seleccionar otros objetos ante al objetivo, ya que quiere convertirse en un testigo de su tiempo. Que Manuel Barrón, un artista formado en la tradición, ejecute una vista del río en la que el protagonista es un "artefacto sin pasado" (RODRÍGUEZ BARBERÁN, 2008: 47) como el Puente de Isabel II -conocido popularmente como Puente de Triana- sirve para testimoniar a la perfección estos cambios.

Resulta singular la coincidencia de que el año en que se ejecuta esta obra -1862- sea el del mencionado periplo de Davillier y Doré por el Guadalquivir. A los viajeros franceses el río no les cau- sa la impresión que produjo en algunos de sus antecesores: apenas hay un breve apunte histórico y alguna critica a su estrecho cauce (DAVILLIER, 1988: 373-379). No obstante, hay en él algo que les interesa mucho más: Ios toros que aparecen en las dehesas sirven de excusa para trasladarnos, a través de un picador con el que comparten el viaje, al peculiar mundo de las corridas. El espacio del río es, para ellos, el marco sobre el cual superponer los trajes típicos, el ritual de la fiesta y la galería de figuras singulares. El Guadalquivir, por tanto, vuelve a multiplicarse: Io pintoresco convive con el presente retratado con la precisión de la cámara fotográfica, y al mismo tiempo se van sentando las bases para que pueda convertirse en el paisaje realista de los pintores que hallarán en él una versión española de la École de Barbizon. Quizás por ello no resulte contradictorio que alguien aficionado a la pintura y acostumbrado a crear sugerentes imágenes con la palabra, el poeta Gustavo Adolfo Bécquer, vea el río como contrapunto de una ciudad que ya no reconoce. En noviembre de 1862 publica en el periódico El Contemporáneo la leyenda La Venta de los Gatos (BÉCQUER, 2004: 327-335). Bécquer expresa en ella su desencanto ante las transformaciones del paisaje urbano y humano de Sevilla, comparándola con sus recuerdos, indudablemente idealizados. Sus paseos por calles y plazas le llenan de insatisfacción, y sólo el Guadalquivir le ofrece consuelo. Alli, precisamente desde el puente de Isabel II, disfruta de un "magnífico panorama", repleto de "mil detalles ... pintorescos"; admira las márgenes repletas de "jardines, palacios y blancos caseríos", y su mirada se pierde en el cauce, con "los innumerables buques ... que desplegaban al aire los ligeros gallardetes de mil colores". La estampa literaria tiene el aire de las postales coloreadas que empezarán a comercializarse en el último tercio deI XIX, y parece convertirse con ello en tránsito simbólico hacia una idealización del río, pero también de Andalucía, que el siglo XX verá nacer. Pero ése es otro paisaje.

\section{En la web}

\section{GUADALOUIVIR, RÍO DE HISTORIA} www.guadalquivirriodehistoria.es

Organización dedicada a divulgar el patrimonio cultural en torno al río Guadalquivir. El sitio web muestra la ruta "Derroteros del Guadalquivir", sobre el Guadalquivir de los siglos XVI al XVIII. Jornadas y exposiciones son algunos de los recursos disponibles.

\section{ASOCIACIÓN COMARCAL GRAN} VEGA DE SEVILLA

wWw.gvs.es

Este sitio web presenta tanto el Plan Estratégico Gran Vega (2007-2013) como información sobre los municipios que conforman la comarca de la Gran Vega.

\section{CONFEDERACIÓN HIDROGRÁFICA DEL GUADALQUIVIR \\ www.chguadalquivir.es}

En el portal web de este organismo podremos encontrar información exhaustiva sobre la demarcación hidrográfica del río Guadalquivir, datos socioeconómicos, información medioambiental y cartográfica, entre otros recursos de interés.

\section{SCARPIA}

www.scarpia.es

Espacio para la creación contemporánea en el municipio cordobés de El Carpio. En este sitio web se puede encontrar un recorrido por las intervenciones y conferencias realizadas desde el 2002 junto a referencias de webs de los distintos artistas participantes e invitados. Presentación de las últimas jornadas realizadas: Jornadas de Intervención Artística en el Espacio Natural y Urbano.

\section{JARDÍN BOTÁNICO DE CÓRDOBA}

www.jardinbotanicodecordoba.com

El molino de Martos forma parte del patrimonio etnológico y etnobotánico del Jardín botánico de Córdoba. Su sitio web ofrece información histórica, glosario e imágenes del molino así como su relación con el entorno.

\section{CÓRDOBA EN 3D}

martoos.blogspot.com

Animación 3D del molino de Martos así como imágenes históricas es lo que podemos encontrar en este blog.

\section{AYUNTAMIENTO DE PEÑAFLOR (CÓRDOBA)}

www.penaflor.es

La web del Ayuntamiento de Peñaflor ofrece información sobre la historia del municipio, con datos del enclave romano de Celti. 


\section{Scarpia, laboratorio de arte a orillas del Guadalquivir}

Desde su nacimiento en 2002, Scarpia se plantea como unas jornadas de intervención artística en los espacios naturales y urbanos del municipio de El Carpio, una localidad de tan sólo 4500 habitantes a 30 km de Córdoba capital. A lo largo de las distintas ediciones, se han producido y realizado más de 120 intervenciones en el paisaje de El Carpio y se han celebrado un centenar de conferencias de la mano de arquitectos, paisajistas, artistas e historiadores. Además, Scarpia ha contado con la presencia de artistas como Daniel Canogar, Rogelio López Cuenca o Mateo Maté, entre otros, que han impartido distintos talleres de creación.

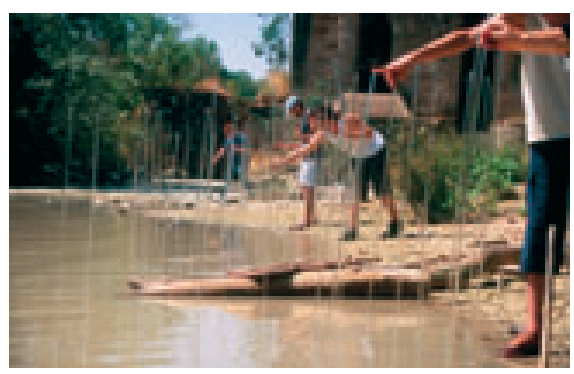

El Canto de Jaurosky, de Manuel Muñoz Foto: Manuel Muñoz

De esta forma Scarpia se ha ido consolidando como un laboratorio de ideas y proyectos de creación sumamente dinámico, en lo que a planteamientos de arte del paisaje se refiere.

El Carpio presenta multitud de registros paisajísticos: el casco urbano vivo, rico y diverso -dominado por la Torre del Homenaje del castillo de Garci-Méndez de Sotomayor-se funde en sus inmediaciones con la campiña y con el Guadalquivir, que baña sus tierras. Esto hace que las producciones específicas de arte



Todos los caminos llevan aroma, de Monique Bastiaans. Foto: Marianna Papapietro contemporáneo, en este contexto, incorporen un interés añadido al rico patrimonio de esta localidad.

Varias intervenciones artísticas, a lo largo de sus ocho ediciones, han mirado al río y han dejado tras de si muchos planteamientos acerca del Guadalquivir, sus valores patrimoniales y sociales, haciendo reflexiones con una visión critica, poética y experimental a través de instalaciones, fotografías o performances de artistas como Ángel Garcia Roldán, Manuel Muñoz, Antonio R. Montesinos, Monique Bastiaans, Miguel Gómez Losada o Sara Moyano.

La vitalidad de la naturaleza, la problemática del medio ambiente, la música o la opera, han sido los discursos que han tocado algunas de las actuaciones realizadas, como la de Martín Solis Moreno, en la primera edición, que realizó con piedras una gran Arroba (@), parafraseando la creación del universo de la Spiral Jetty del artista americano Robert Smithson. En este caso se evoca el nuevo mundo virtual que nos ha tocado vivir jugando directamente con un icono del Land Art.

En el año 2004 el fotógrafo Manuel Muñoz realizó una intervención que se titulaba El Canto de Jauros$k y$, livianos juncos de cristal cuya escenografía eran las grúas, los molino del río. La fragilidad del cristal creaba tal tensión con el agua y el barro del río que parecia que de un momento a otro se rompiese tan delicado material, el agua y el viento susurraban por los agujeros de estos juncos de cristal que se iban hundiendo en el río como si se fundieran con el verde del Guadalquivir, produciendo una atmósfera irreal.

Sara Moyano realizó, en el 2006, Frágil, una balsa hecha de fragmentos de botellas de agua, instalada

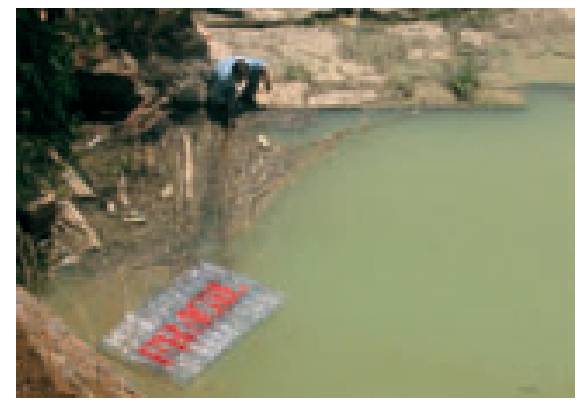

Frágil, de Sara Moyano. Foto: Miguel Ángel Moreno Carretero

durante 10 dias en un lugar donde las corrientes del río acumulan residuos. La obra parecia hecha por el propio río pidiendo auxilio.

Le Petit Tour fue un proyecto realizado por Antonio R. Montesinos para la última edición de Scarpia. En él se reflexionaba en torno a la actividad turística de la ciudad de El Carpio, estableciendo una relación entre el paisajismo como género artístico y el senderismo como fenómeno de "práctica del paisaje". La intervención en el espacio se alejaba de la idea de monumento, ya que no se colocaba ningún objeto grandioso en él. En lugar de eso se daba protagonismo al propio espacio natural intervenido, encontrando lo grandioso en el propio paisaje por medio de su exploración y marcado. El proyecto sigue en http://www.armontesinos.net/lepetittour/.

Miguel Ángel Moreno Carretero Scarpia

Maria Anna Papapietro

Centro de Documentación y Estudios del IAPH

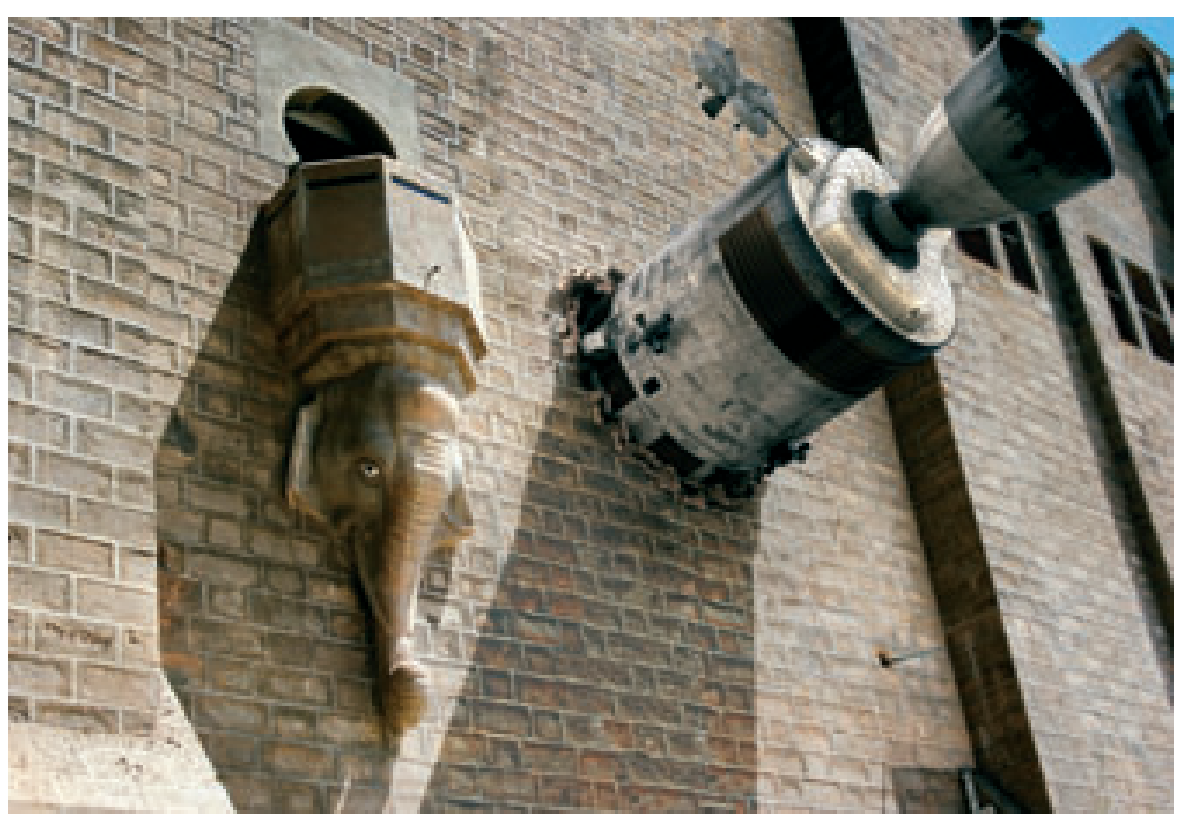

Fotomontaje de Manolo Bautista sobre la presa de El Carpio 


\section{CELTI. Un municipio romano en la campiña sevillana}

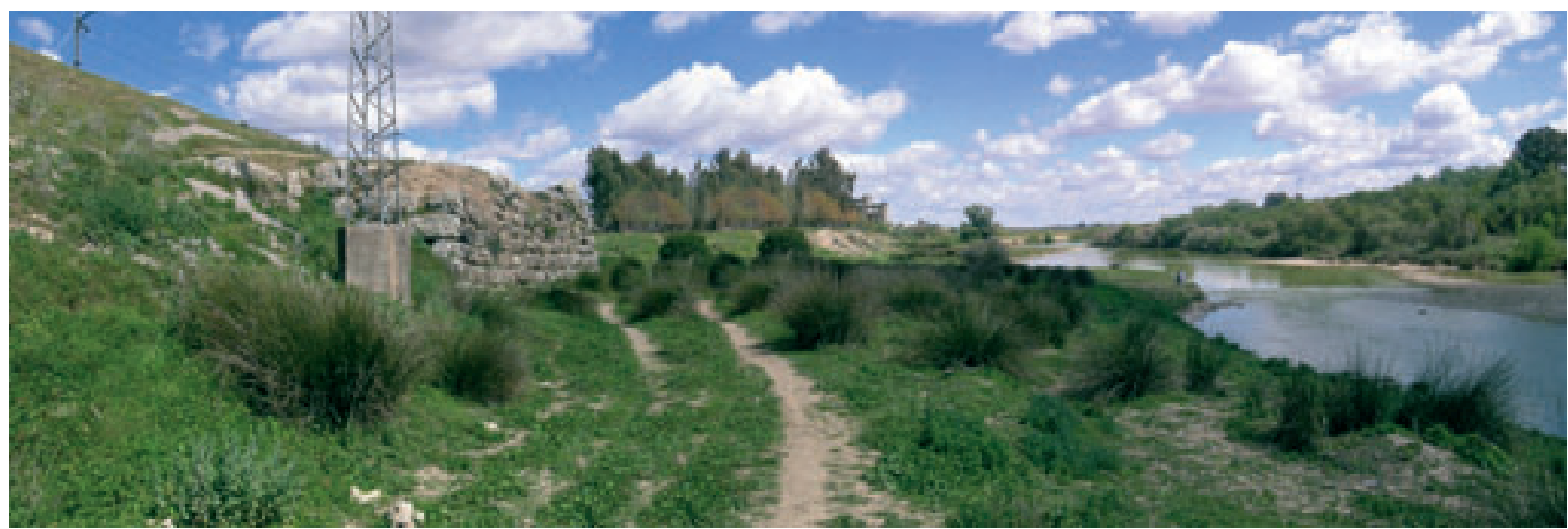

El Higuerón, estructura ciclópea a orillas e Guadalquivir, cuya cronología y funcionalidad concreta se desconoce. Foto: Juan Antonio Fernández Naranjo

En la antigüedad, al igual que en la actualidad, no en vano somos herederos del pasado, el último tramo de la margen derecha del río Guadalquivir estaba salpicado por multitud de asentamientos y ciudades. También entonces, primero el Tartessos, después el Baetis y finalmente el Al-wadi al-Kabir era fuente de vida, propiciaba recursos y constituía una vía de comunicación que posibilitaba las relaciones comerciales y permitía el contacto entre los habitantes del territorio. Ese territorio empezó a poblarse de forma estable entre los siglos IX y VIII a. C., cuando las poblaciones indigenas empezaron a buscar y asomarse a sus orillas para facilitar los contactos comerciales, especialmente activos tras la llegada de los fenicios al sur de la península ibérica.

Desde Córdoba hasta Coria del Río, donde se situaba la desembocadura, la margen derecha del Guadalquivir está repleta de yacimientos de mayor o menor entidad. Algunos, los mejor ubicados, llegaron a ser municipios romanos, todos ellos con puertos fluviales.



El Pelote, capitel romano de mármol usado como cantonera en la esquina entre las calles Nueva y Blancaflor. Foto: Juan Antonio Fernández Naranjo
Entre ellos Celti y junto a él otros tantos; tantos cómo pueblos en la actualidad. Si partiéramos de Corduba navegando río abajo buscando la desembocadura y el mar abierto para adentrarnos en el Mediterráneo, siempre en la margen derecha, nos encontraríamos con Carbula (Almodóvar del Río), Detumo (Posadas?), Celti (Peñaflor), Axati (Lora del Río), Arva ("El CastiIlejo", en Alcolea de Río), Canama (Alcolea del Río), Naeva (Cantillana), Ilipa Magna (Alcalá del Río), Italica (Santiponce), Hispalis (Sevilla), Osset (San Juan de Aznalfarache) y Caura (Coria del Río).

La situación de Celti se eligió para garantizar y jugar un papel dominante en la vida económica, social, política y cultural en el bajo valle del río. Ocupaba un punto intermedio entre Corduba (la capital de la provincia) e Hispalis, a cuyo conventus pertenecia. Su ubicación física no era caprichosa, ya que se buscó una elevación topográfica destacada en una encrucijada de caminos próxima a la desembocadura del Genil (Singilis) en el Guadalquivir, lo que le permitía el contacto con Astigi (Écija) y desde aqui hacia la sierra subbetica y la parte más oriental de la provincia, donde nace el Genil -Sierra Nevada-. También a través de Astigi accedía a la Vía Augusta (Nacional IV), que reforzaba sus relaciones comerciales terrestres con otras ciudades, como Carmo (Carmona) y Obulcula (Castillo de la Monclova, en Fuentes de Andalucía). Ambas vías de comunicación envolvian un territorio, la actual campiña, que era aprovechada por los citados municipios romanos para la explotación agrícola (vid, olivo y cereal) y ganadera (cabra, oveja y cerdo).

Completando la explotación de esos recursos, hacia el norte, y ahora por vía terrestre, una serie de pasos naturales permitian la conexión con Sierra Morena, alcanzar el Guadiana (Anas) y la capital lusitana (Emerita Augusta). A través de ellos también conectaban con las ricas reservas de metales de la región, que se encontraban bastante más al Oeste (norte de Huelva) y hacia el Este (cerca de Córdoba). Finalmente, también con zonas de laboreo minero más próximos, como los existentes en la actual Puebla de los Infan- tes, de donde extraerian cobre, oro y plata; y también las gestionadas por el municipio flavio de Muniqua (Villanueva del Río y Minas), desde donde se explotaba la falla minera de El Pedroso, rica en hierro, cobre y el oro cautivo que éste suele llevar asociado.

Frente a la fuerte carga simbólica e historiográfica que desde antiguo rodeó a Italica, Corduba o Hispalis, la difusión arqueológica de estos municipios romanos que se asoman al rio fue mucho más reciente y residual, aunque ya eran conocidos por los humanistas e ilustrados que manejaban las fuentes antiguas y se interesaban por la epigrafia y la numismática. No se generalizará hasta fines del siglo $X_{I}$, al igual que la de cualquier otro yacimiento del país, cuando se interesaron y establecieron en el sur peninsular extranjeros como G. Bonsor, A. Engel, P. París, o A M. Huntington, que colaborando con los arqueólogos locales publicaron en sus lenguas vernáculas los hallazgos que se producian. Unos, como el joven pintor G. Bonsor, lo hicieron atraídos por el pintoresquismo que relataban los libros de viajes y otros siguiendo las huellas del epigrafista alemán Emil Hübner, que en 1869 había publicado el volumen de CIL dedicado a Hispania. La epigrafía junto con la numismática sirvió para identificar las ciudades citadas en las fuentes clásicas, que en el caso de Celti son en Plinio el Viejo (HN3, 11), en el Itinerario Antonio (It. 414,5), en el Cosmógrafo de Rávena (Rav. IV. 44 315.2), o en el II Concilio Hispalense del año 619.

Conocida la epigrafía y las monedas con la leyenda Celtitan, las primeras descripciones que demostraban el potencial arqueológico del yacimiento se deben a George Bonsor, quien desde Carmona y Mairena del Alcor visitó y colaboró en la investigación de todos los grandes yacimientos de la Baja Andalucia (Carmona, Los Alcores, Bolonia, Itálica, etc.). Aceptada desde antiguo la identificación de Celti con Peñaflor, G. Bonsor describió los restos ciclópeos de "El Higuerón", un columbario familiar en el "Cortinal de las Cruces", ataúdes de plomo, restos de edificaciones en "Pared Blanca", el trazado del acueducto y hornos cerámicos de ánforas. 
Curiosamente, valorada la explotación aceitera de la Bética y su comercialización por el Imperio y en especial con la gran metrópoli (M. Ponsich, L. Abad, G. Chic y J. Remesal), tras un leve balbuceo arqueológico emprendido por el Museo Arqueológico Provincial y la Delegación Provincial de la Consejería de Cultura en la década de 1980, será otro extranjero quién se interese por Celti.

Entre 1987 y 1992, al frente de un nutrido equipo de investigadores británicos con colaboradores locales, el arqueólogo hispanista Simon Keay dirigió un Proyecto General de Investigación en Celti (Peñaflor) (KEAY et ál., 2001). Gran conocedor e interesado en los procesos de romanización en su relación con los pueblos indigenas, tras las experiencias de la Tarraconense, centró sus intereses en este municipio romano. Con los precedentes y estado de la investigación, durante cinco años planteó intervenciones arqueológicas con el fin de dar respuesta a una serie de cuestiones relacionadas con el yacimiento, su evolución y papel desempeñado durante el proceso de romanización del sur peninsular.

Entre otros objetivos interesaba saber la fecha en que el yacimiento adquirió el carácter urbano y las posibles relaciones con los coetáneos yacimientos fenicios y cartagineses. También el impacto de Roma en la ciudad tras la conquista del sur de Hispania, la romanización de la ciudad durante los últimos momentos de la República e inicios del Imperio, o el papel desempeñado por la ciudad en la economía de la provincia, especialmente con respecto a la producción y exportación de aceite de oliva en ánforas Dressel 20. Todo ello reforzado por un minucioso estudio de la epigrafía celtitana.

Los resultados obtenidos, sumados al estado general de la investigación histórica y arqueológica, permiten afirmar que en el valle del Guadalquivir el patrón de asentamiento romano no se establece firmemente hasta mediados o fines del siglo I a. C. Con anterioridad a estas fechas, los centros de poder romano tan sólo habian quedado establecidos en Italica y en Corduba. A partir de ese momento, tras la conclusión de las guerras civiles, Cesar y Augusto establecieron en el valle del Guadalquivir y tierras adyacentes una serie de colonias como Hispalis (Sevilla), Astigi (Ecija), Urso (Osuna), Corduba (Córdoba), Itucci (Torreparedones?, Córdoba), Ucubi (Espejo) y Tucci (Martos). Estas colonias, junto con otras ciudades nativas a las que se les concedió el estatuto municipal, fueron conectadas por una red viaria y agrupadas en cuatro distritos judiciales: los concentus hispalensis, cordubensis, gaditanus y astigianus. Todo ello en el marco de la recién creada provincia Hispania Ulterior Baetica, con capital en Corduba. Pese a ello, el número total de nuevas ciudades romanas y las nativas romanizadas era todavia bajo en comparación con la mayoría de los asentamientos de la región, cuya población debió mantenerse inicialmente ajena a esos cambios. El análisis de los datos arqueológicos relativos a la formación de paisajes urbanos y la construcción de edificios públicos a la romana sugiere que esa transformación no se produjo hasta fines del siglo I d. C., en gran medida debido a la decisión política dada por los emperadores flavios de concederle el ius latii a todas las comunidades de la provincia.

Esa transformación está bien documentada en $\mathrm{Mu}$ nigua y también en Celti, ya que de este momento datan los epígrafes más antiguos y también algunos edificios del foro. Desde este momento hasta el siglo III d. C., esa epigrafia nos habla de una serie de familias celtitanas, como los Fabii, Aelii, Aemilii, Annii, Brutii, Caesii, Fulvii, Licinii, Lurii o los Sempronii, que sin descartar la explotación de productos de distribución más local y si olvidar el vino se lucraban, al igual que otras familias de los vecinos municipios, con la producción y la comercialización del aceite de

Mausoleo romano labrado en la roca, posteriormente reutilizado como Capilla de los Santos Mártires. Planta-Sección. Dibujo: Juan Antonio Fernández Naranjo

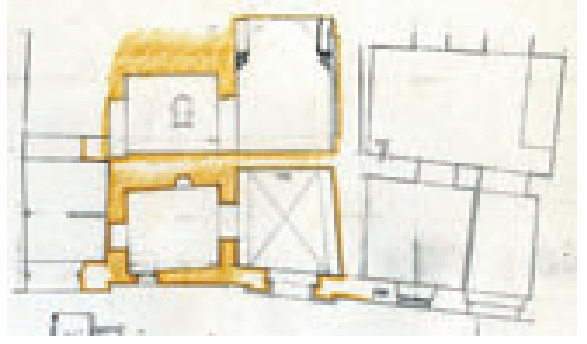

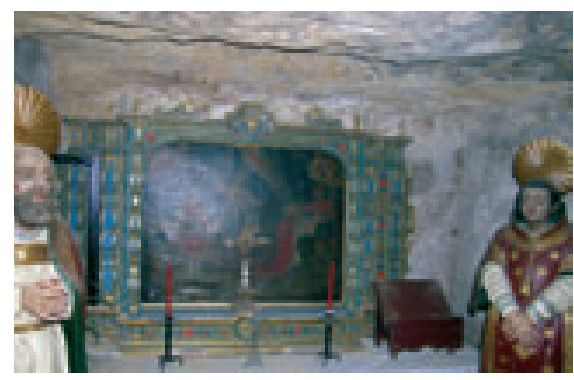

Mausoleo romano labrado en la roca, posteriormente reutilizado como Capilla de los Santos Mártires Críspulo y Restituto.

Foto: Juan Antonio Fernández Naranio

oliva. En el territorio de las ciudades citadas, a orillas del Genil y Guadalquivir, se han localizado más de un centenar de yacimientos que en su día se dedicaron a la manufactura de ánforas para el transporte del aceite, que finalmente se canalizaba y difundia por todo el Imperio a través del puerto de Hispalis, hasta que a mediados del siglo III d. C. la Bética dejó de ser el principal proveedor de aceite de Roma y las fronteras.

Desde esos momentos y hasta el siglo VII, con los profundos cambios administrativos políticos y económicos sufridos por la Bética, este municipio, al igual que otras ciudades de las provincias periféricas, quedó marginado y especialmente perjudicado cuando a principios del siglo IV Corduba dejó de ser la capital de la diócesis hispaniorum en favor de Emérita Augusta. Poco después, desde principios del siglo $V$, la arqueología documenta una gran ruptura y desintegración de la estructura urbana que generó un nuevo paisaje urbano, que coincide con el momento en que el control romano pasó a manos de vándalos, suevos y visigodos, aunque es mucho lo que queda por investigar. Pese a ello, reconociéndose el potencial arqueológico de Celti y sus valores patrimoniales, el yacimiento fue declarado BIC, con la categoría de Zona Arqueológica, el 18 de enero de 1994.

José Manuel Rodríguez Hidalgo

Delegación Provincial de Cultura de Sevilla

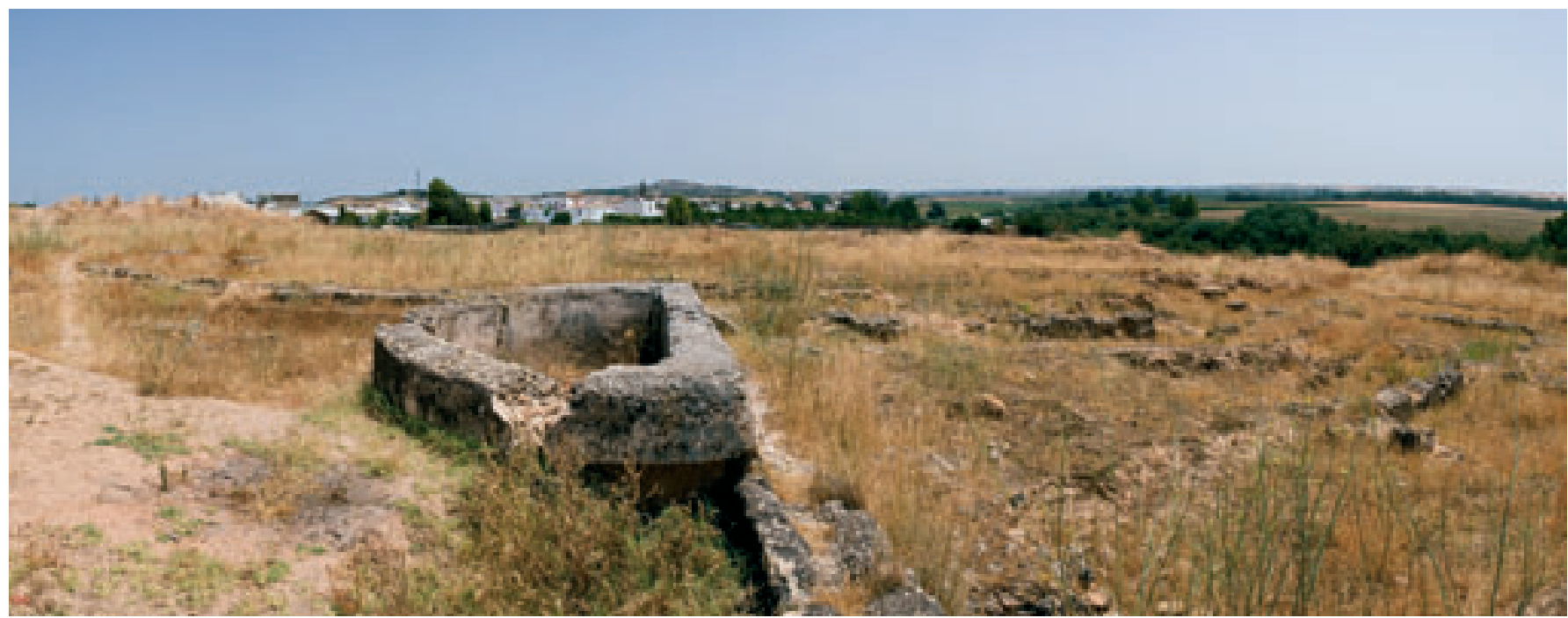

Restos del área forense de Celti en La Viña (Peñaflor, Sevilla). Foto: Juan Carlos Cazalla, IAPH 




Puente romano de Andújar (Jaén). Foto: Juan Carlos Cazalla, IAPH 


\section{Infraestructuras del transporte: los puentes}

Francisco Javier Rubiato Lacambra, Dpto. Ingeniería Civil: Ordenación del Territorio, Urbanismo y Medio Ambiente, Universidad Politécnica de Madrid

\section{EL Río}

Antes de centrarnos en las infraestructuras de transporte en el Guadalquivir hay que hacer unas breves reflexiones sobre el propio río. Como todos sabemos el Guadalquivir es el eje geográfico de Andalucía. A modo de columna vertebral, estructura el territorio de Este a Oeste, a pesar de dar sus primeros pasos en dirección Nordeste, trayectoria que cambia al recibir al Hornos. De ser un pequeño río en la Sierra de Cazorla, fluyendo entre montañas, pasa poco después, en su singular discurrir, a constituirse en límite entre Sierra Morena y la Campiña, para una vez pasada la ciudad de Córdoba, centrar su posición en el valle, y llegar así hasta la desembocadura. Esta disposición dentro del territorio de nuestra región llevó desde antiguo a que el río se constituyera, primero como vía de penetración, y después en eje de comunicación en el territorio. Con más importancia, si se tienen en cuenta las dificultades topográficas que representan las cordilleras Béticas y la complicada disposición de las sierras que las conforman.

Por lo expuesto no es de extrañar que desde tiempos remotos los márgenes del río fueran utilizados como vías de comunicación. Uso éste que quedo definitivamente fijado con la dominación romana, primero con la vía Hercúlea y luego con la vía Augusta, que comunicaban directamente nuestras tierras con la capital del Imperio, como aun queda atestiguado en los miliarios. Pero no solo los márgenes fueron utilizados para la comunicación. El propio cauce sirvió durante siglos como vía. La escasa pendiente facilitaba su uso. Existen referencias a que en tiempos de los musulmanes se podía llegar navegando hasta Villa del Río, límite oriental de la actual provincia de Córdoba, y que allí una cadena tendida sobre el cauce señalaba el final de dicha posibilidad. Los constantes acarreos de materiales propiciados por la misma corriente, la diferente pluviosidad actual y el desarrollo de las técnicas del transporte, han conllevado al abandono de esa práctica. Hoy solo en uso desde la desembocadura hasta Sevilla. Aunque no hace tanto, en la segunda década del siglo pasado, en concreto en 1919 el ingeniero Carlos Mendoza presento al ministro de Fomento su Proyecto de Canalización y aprovechamiento de energía del Guadalquivir entre Córdoba y Sevilla, en el que aprovechaba los
$88 \mathrm{~m}$ de desnivel existente en los $177 \mathrm{~km}$ de longitud del tramo con once presas y sus correspondientes esclusas para permitir la navegación (AGUILÓ, 2002: 113).

\section{CAMINOS Y PUENTES}

Desde tiempos remotos la fertilidad de las tierras aportadas por el río ha favorecido la ocupación del territorio. A su vez el poblamiento y la topografía del valle han propiciado las comunicaciones y con ellas la creación de un sin fin de caminos. Es en este momento cuando el río, además de eje integrador, separa. La necesidad de continuar el camino hace imprescindible la presencia del puente.

El Guadalquivir es un río con un gran patrimonio en puentes. En el aparecen muy bien representadas todas las etapas histórico constructivas. Desde los remotos tiempos de los romanos hasta la actualidad. No se puede olvidar que la Bética fue una de las primeras regiones que se civilizó y urbanizó, y que por aqui han pasado gran número de pueblos. Con los puentes, el río intensifica su capacidad de integración del territorio: une ambas orillas, pone en contacto a las gentes, reúne tierras y crea un paisaje común.

Los puentes, desde siempre, y estén donde estén, nuestro río no es una excepción, son el resultado del esfuerzo común de muchos ciudadanos anónimos, que desde la simple aportación económica al esfuerzo físico e intelectual han contribuido a fomentar las comunicaciones, los intercambios, el comercio. Estas estructuras (los puentes) son el resultado de la superación constante. De ahí que en ellos aparezcan reflejados los más importantes avances técnicos y científicos de los pueblos que los construyeron, así como son fruto también de su pensamiento estético y reflejan fielmente la situación económica, política y social de cada momento, es decir su historia.

\section{PUENTES ANTIGUOS}

Como antes se ha dicho, en el Guadalquivir los puentes se han construido desde tiempos remotos. No queda ningún resto ante- 
rior a Roma. Es probable que existiera alguna obra, quizá próxima al nacimiento. De este modo los puentes más antiguos que han llegado hasta nosotros corresponden a este periodo. Con su política de expansión territorial, Roma creó una vasta red de vías y caminos. Como consecuencia se facilitaron las comunicaciones como nunca se había conseguido. Además, se produjo, por primera vez, más allá de la urbanización de nuevos núcleos de población, una ordenación del territorio peninsular y, en el caso que nos ocupa, de la Bética (SÁENZ, 1984: 138-153).

Dentro de la estructura viaria romana los puentes se constituyen como elementos singulares. Su aparejo es siempre de fábrica de piedra, cortada en grandes sillares, utilizando en el interior de las pilas y en las fundaciones el hormigón. Estas siempre solian coincidir con el terreno más consistente de la zona ya que colocaban los apoyos preferiblemente sobre roca (VITRUVIO POLIÓN, 1995: Libro III, Cap. IV). Utilizaban las bóvedas de cañón de modo sistemático. Éstas se apoyaban sobre robustas pilas, en ocasiones con una anchura exagerada en relación al vano, muchas veces se superaba el tercio de éste, lo que podía resultar problemático pues creaba una fuerte resistencia frente a la corriente. Las pilas se completaban con tajamares solo aguas arriba y sobre los mismos se situaban los sombreretes. Las bóvedas se destacaban del paramento por la disposición de las dovelas. La línea de impostas señalaba la diferencia entre el tímpano y el pretil siempre de piedra. Sobre el Guadalquivir solo quedan dos puentes de este periodo, el de Andújar y el de Córdoba. Ambos han sufrido a lo largo de la historia gran número de reparaciones e intervenciones que los han ido modificando. El segundo ha sido durante siglos el ultimo paso estable para cruzar el río antes de la desembocadura. Los tramos bajos de los ríos fueron los únicos obstáculos que los romanos no pudieron salvar. En Sevilla el paso se realizaba por medio del puente de barcas, de origen antiguo pero posiblemente posterior a la dominación romana.

No fueron los únicos que existieron sobre el río. Hay que tener presente la intensa romanización de la Bética. De este modo el actual puente de Úbeda La Vieja, puente medieval, sin duda fue en su origen una obra romana transformado muy probablemente en el siglo XIII (FERNÁNDEZ CASAD0, 1981). Lo mismo sucedió con el viejo puente de Alcolea del Río, sustituido en tiempos de Carlos III, como atestigua Ponz (1988: tomo XVI, carta sexta). También en las proximidades de Villanueva de la Reina, en Jaén, debió existir otro, como queda reflejado en los planos del proyecto del actual. A estos cinco habría que añadir la más que probable transformación del antiguo puente de las Herrerias por Ios Reyes Católicos (RUBIATO LACAMBRA, 2005:30). En cuanto a la Edad Media en nuestro territorio los musulmanes se caracterizaron por una política de aprovechamiento y restauración de los puentes romanos (PAVÓN MALDONAD0, 1990: 91). En algunas ocasiones además se añadieron elementos defensivos como la construcción de la torre de La Calahorra en el puente Romano de Córdoba (FERNÁNDEZ TROYANO, 1985: 11 y 28).

\section{RENACIMIENTO Y MODERNIDAD}

La modernidad entra en España de la mano de los Reyes Católicos. Los monarcas marcar las nuevas directrices políticas, al crearse la monarquía autoritaria frente al poder feudal. Los nuevos objetivos político-sociales llevan a los reyes a reactivar la construcción y mejora de caminos, así como la reparación y construcción de nuevos puentes se produce asi una intensa labor de modernización (NOVÍSIMA, 1980: 92), concentrándose la mayor cantidad de nuevas obras en la mitad sur del territorio, donde fue escenario privilegiado Andalucía y en concreto el Guadalquivir. Asi entre los siglos XV y XVI sobre nuestro río se construyeron cinco puentes'. Además de la corona hubo otros promotores como el obispo Alonso Suárez de la Fuente, que promovió la construcción del puente del Obispo en Baeza, e incluso en ocasiones el mismo pueblo se convirtió en promotor de la construcción del puente. El mejor ejemplo en este sentido nos lo da el de Montoro (RAMÍREZ DE LAS CASAS, 1986: 115). Los reyes conscientes de la importancia y de las dificultades del empeño eximieron del pago de tributos y gabelas a toda la localidad cordobesa.

El puente de la modernidad coincide con el renacer de la cultura y de las artes. Pero sigue siendo heredero de los hallazgos técnicos romanos. Así se estudian las obras antiguas. A pesar de ese deseo de enlace con la antigüedad, las bóvedas renacentistas se despegan de sus modelos romanos a causa de su mayor luz. Las roscas de las mismas suelen tener alguna concesión a lo decorativo, resaltando el extradós. En cuanto a la rasante de los tableros el ideal es la plana, pero no siempre se logra. En lo referente a la fábrica, el paramento es de piedra cortada en sillares lo más regulares posibles. Respecto a las pilas y sus fundaciones se buscan siempre los puntos más firmes. Estas se refuerzan con tajamares, en este periodo, situados tanto aguas arriba como abajo, triangulares los primeros y semicirculares los segundos. Una innovación de estos tiempos es la prolongación del tajamar hasta la altura de la rasante del tablero. Se crea de este modo un ensanche en el tablero denominado apartadero. Los pretiles seguirán siendo de sillería. Sobre el Guadalquivir se construyeron los puentes de Las Herrerías, Montoro, Mazuecos, el del Obispo y Marmolejo, magníficos ejemplos de ingeniería renacentista.

Es obligatorio para terminar este periodo citar las obras realizadas en el siglo XVIII. Tras un progresivo abandono de los caminos centrado en el siglo XVII, consecuencia de de causas complejas, que no es momento de citar. Se produce un nuevo esfuerzo de renovación. Fruto del cual se construyó en las inmediaciones de Córdoba el puente de Alcolea del Río. Su situación estratégica le ha hecho escenario de acontecimientos trascendentales en la historia de nuestro país. El primero durante la Guerra de la Independencia, el 17 de junio de 1808, batalla en la que el general Pedro Echeverri derroto al general Dupont. Mayor trascendencia para la evolución política de España tuvo el encuentro durante la revolución "Gloriosa" en 1868 de los ejércitos realista, capitaneado por el Marqués de Novaliches, y los sublevados dirigidos por Prim y Serrano, pues decidió el exilio de Isabel II². Se trata de un puente de gran desarrollo longitudinal. Consta de veinte bóvedas. Esta realizado en perfecta silleria. 


\section{A}

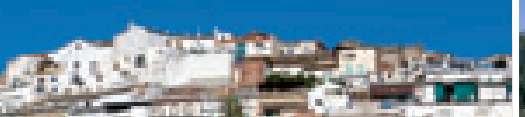
T.

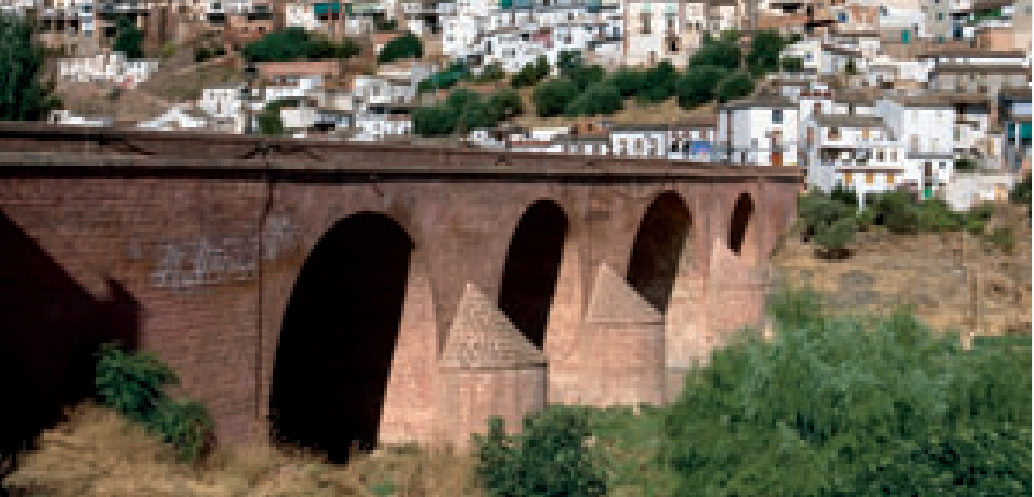


Vista de Montoro (Córdoba) con el puente romano en primer plano.

Foto: Juan Carlos Cazalla, IAPH

Puente de los Remedios. Villafranca de Córdoba. Foto: Juan Carlos Cazalla, IAPH Nuevo puente de Miraflores. Córdoba. Foto: Juan Carlos Cazalla, IAPH

Puente renacentista de Marmolejo (Jaén)

Foto: Francisco Javier Rubiato Lacambra

Puente de hierro de Villa del Río, Córdoba. Foto: Juan Carlos Cazalla, IAPH

Puente Reina Sofía en Palma del Río (Córdoba). Foto: Juan Carlos Cazalla, IAPH 


\section{EL EMPLEO DEL METAL Y LA CONSTRUCCIÓN DE PUENTES}

Aun con cierto retraso respecto de Europa, la revolución industrial marcó la centuria del siglo XIX también en nuestro país. Con ella Ilego a España el hierro que a partir de entonces se aplicará a la construcción de puentes. Con el cambiará radicalmente la concepción de los puentes. Los nuevos sistemas metálicos traerán una auténtica revolución estética. Se desarrolló toda una tipología de vigas. Como elemento decisivo en esta revolución, influyó el desarrollo de un nuevo sistema de trasporte, el ferrocarril. Aunque la nueva tipología de puentes no sea exclusiva del mismo.

En el Guadalquivir se encuentran gran número de puentes metálicos del siglo XIX, o al menos en su origen fueron de dicho siglo. El más destacado sin duda, es el puente de Isabel II en Sevilla. Construido siguiendo al puente parisino del Carrusel utiliza la cercha Polenceau (PUENTE, 1844). También es de destacar el puente de Palma del Río. Éste de vigas rectas armadas y doble celosía, formando dobles cruces de San Andrés (PROYECTO: caja 2123). Ambos destinados a la carretera. El resto son puentes de ferrocarril: Ios de Lora del Río, Tocina, Mengibar, Alcolea, El Alcalde o Baeza. Todos ellos con amplio desarrollo longitudinal debido a los condicionantes topográficos del terreno.

Por su parte, siguieron construyendose puentes de fábrica. También experimentaron una evolución respecto las obras precedentes. Se rebajaran las bóvedas y en general no se dieron licencias decorativas como en siglos precedentes. Las rasantes serán planas igualadas al nivel del camino. Los tajamares disminuyen de tamaño y serán igual en ambos frentes. Los estribos se reforzaran ante la importancia de su misión sustentadora. Todo siguiendo las enseñanzas heredadas de Perronet. En nuestro río solo tenemos dos ejemplos: el puente del Hacha en la sierra de Cazorla, y un tramo del viejo puente de Andujar hundido durante la Guerra de la Independencia (RECONSTRUCCIÓN: cajas $2340,5743$ y 5744$)$.

\section{LA REVOLUCIÓN CONSTRUCTIVA: ACERO Y HORMIGÓN}

En el siglo XX la construcción de puentes llega a un desarroIlo inusitado. No hubiera sido posible sin la utilización de los nuevos materiales: acero y hormigón. El primero, liberó a las construcciones metálicas de la fragilidad ante la corrosión. El segundo en solitario, en principio, y después armado con metal en su interior, aunará las cualidades de la piedra y el metal. Perteneciente al primer tipo en el Guadalquivir se puede destacar los puentes de Villa del Río, Lora del Río, o el móvil de San Juan de Aznalfarache, todos de carretera, en cuanto al segundo tipo, de hormigón en masa, destacan el puente de Megíbar de la antigua carretera de Bailén a Jaén y el de San Rafael en Córdoba (RUBIATO LACAMBRA, 1997: 523), y de hormigón armado los de Villanueva de la Reina, el de la Cerrada de Utrero en Cazorla, Jaén, y el de San Telmo en Sevilla, entre otros muchos.
El invento del pretensado por el ingeniero francés Eugéne Freyssinet supondrá aún un mayor avance en las posibilidades constructivas del hormigón. Como consecuencia se fabrican las piezas en las márgenes y se montan por medio de voladizos sucesivos. Este sistema fue utilizado por primera vez en 1962 en España sobre el Guadalquivir en el Puente de Almodóvar del Río, obra del ingeniero Carlos Fernández Casado. Se produce así una autentica revolución constructiva que ha permitido la construcción de gran número de carreteras y de puentes. Además de estos novedades, se dio otra línea de actuación, si cabe más sorprendente, las obras mixtas. En las que hormigón y metal colaboran unidos pero no mezclados. Una de las primeras obras de este tipo será la del puente de Posadas sobre el Guadalquivir. Iniciado antes de la Guerra Civil, tras ella, se hizo cargo de su construcción Eduardo Torroja imprimiéndole su audacia y originalidad (PÁEZ BALACA, 1950: 206). Esta técnica ira evolucionando y será aplicada a los nuevos métodos constructivos de viga-cajón y unión de dovelas, consiguiendo bellísimos puentes como el de El Arenal en Córdoba, o el de la autovía en Mengibar.

No se puede acabar esta reflexión del Guadalquivir y sus puentes sin al menos citar la Expo del 92 por la trascendencia que tuvo en dicha cuestión. Es verdad que se centró, afectó y transformó especialmente a Sevilla. Para ello fueron necesarios años de debate hasta que en 1987 se aprobó El Plan General de Obras Urbanas de Sevilla. Con él, además de la apropiación de la isla de La Cartuja como zona urbana, una vez solucionados los problemas de las periódicas inundaciones con las que el río sometía a la ciudad, se construyeron diez puentes. A parte de estos, se realizaron y proyectaron otros en la ciudad de Córdoba, también sobre el Guadalquivir, como el ya citado de El Arenal, el de Miradores, o el de Andalucía y los correspondientes a la transformación de la carretera N-IV en autovía. Pero la explosión constructora de Sevilla no solo fue importante por la cantidad de puentes construidos, sino por la calidad del diseño, la variedad tipológica: Iosas ortótropas, atirantados, arcos metálicos, etc., los magníficos materiales utilizados y los procesos constructivos. Puentes como el de La Barqueta, La Cartuja, Chapina, Las Delicias, El Alamillo, o el Quinto Centenario, por citar solo unos pocos, supusieron un salto cualitativo que ha situado a la ingenieria española en los primeros a nivel mundial.

Hoy, ya en el siglo XXI, el río sigue su fluir. También sigue nuestra actividad, con ella se necesitan nuevas comunicaciones. Estas precisan de nuevos puentes, como el recién construido de la variante de Montoro o el nuevo de Palma del Río. Obras de hoy, que reflejan unas técnicas, un tiempo y una forma de vivir. Sin duda son también una aportación más al ya rico patrimonio histórico de puentes del Guadalquivir.

\footnotetext{
Notas:

${ }^{1}$ Los otros puentes construidos en este periodo en Andalucia fuera del Guadalquivir son los de Benameji, Puente Genil y Ariza.

${ }^{2}$ Mapa de la batalla de Alcolea. Archivo Cartográfico del Ejército, documento 274.
} 


\section{El museo hidráulico o Museo del Agua de Córdoba}

El Museo Hidráulico de Córdoba tiene su sede en un antiguo molino harinero, el Molino de Martos, situaGuadalquivir antes de entrar en la ciudad. Recibe este nombre por estar ubicado cerca de la puerta homónima en la antigua ciudad amurallada. Este molino medieval fue rehabilitado por el arquitecto santanderino Juan Navarro Baldeweg e inaugurado en el año 2006 por la, en ese momento, Alcaldesa de Córdoba, Rosa Aguilar Rivero, como Museo Hidráulico (MONTERO et ál., 2007). Recientemente ha sido declarado Monumento Histórico dentro del patrimonio histórico andaluz, junto con el resto de los molinos del río en el tramo urbano cordobés. Es el tercer molino de agua que se rehabilita de los once que hay en el río a su paso por la ciudad y forma parte de un "Plan especial de recuperación del río y ribera", que el Ayuntamiento de Córdoba lleva años ejecutando.

El molino es un edificio con una larga trayectoria y su origen hay que situarlo en época árabe, durante la cual se llamó Molino de Albolabez. Fue aceña (molino de rueda vertical), hasta el siglo XVI, cuando paso a convertirse en molino de regolfo (molino de rueda horizontal), ampliándose el edificio con tres salas para batanes de paños que lo dotaron de su fisonomía actual. En la segunda mitad del siglo XIX sufrió una importante transformación en la zona de los batanes, desapareciendo éstos e instalándose dos turbinas eléctricas, una en cada sala, dejándose la tercera para almacén (CÓRDOBA DE LA LLAVE et al., 2005). Este cambio no es apreciable desde el exterior. la molienda del grano para la fabricación de harina, excepto, lógicamente, la parte de los batanes en donde se abatanaban tejidos para la industria pañera cordobesa. La instalación de ingenios eléctricos en el siglo XIX, destinados también a la molienda de cereal, fue un último intento de hacer el molino rentable en un momento de clara decadencia de estos edificios. do dentro del cauce, en el meandro que hace el Río

Este molino ha tenido, desde su origen, el mismo uso:
El edificio, rehabilitado en su totalidad, es visitable como parte del Museo. La exposición ocupa una pequeña sala que constituye también un mirador sobre el río y la ribera. El resto del inmueble consta de la sala de molienda y tres salas anexas en la que históricamente se ubicaban batanes de paños.

El molino, singular en si mismo, muestra al visitante, en la planta alta la sala de exposición en donde la abundante información gráfica, pretende mostrar al público el camino seguido por el cereal desde la campiña al molino, y posteriormente a los hornos y, ya transformado en pan, su salida al mercado cordobés.

Una película enseña el funcionamiento de un molino de agua de rueda horizontal o de regolfo. También hay dos maquetas, la primera muestra la situación de los cuatro molinos más conocidos en Córdoba, en las cercanias del puente romano, en la llamada parada del puente, y la segunda muestra la arquitectura interna del molino de Martos, incluyendo toda la estructura de molienda. Esta consiste en lo siguiente:

- Por debajo de la sala de molienda se sitúa un cubo o cubete. El agua entraba en el cubete por una abertura en la parte superior, tangencialmente, y salia por otra en la parte inferior. En el fondo de este cubete se alojaba la rueda horizontal que conectaba con las piedras de la sala de molienda.

- Dentro de la sala de molienda, está el empiedro, consistente en un banco hecho de fábrica y dos piedras de moler, una fija o solera y otra móvil o corredera que conectaba con la rueda situada en la parte inferior, dentro del cubete, mediante un eje.

El cierre lateral de la sala de exposición al Sur y Oeste presenta una sucesión de grandes cristales verticales entre paneles verticales metálicos, que la convierten en un mirador sobre la ribera, permitiendo observar una sucesión de paisajes, que van desde la vista del río y meandro, con la vegetación de ribera y bosque de galería, a la vista general del casco antiguo con

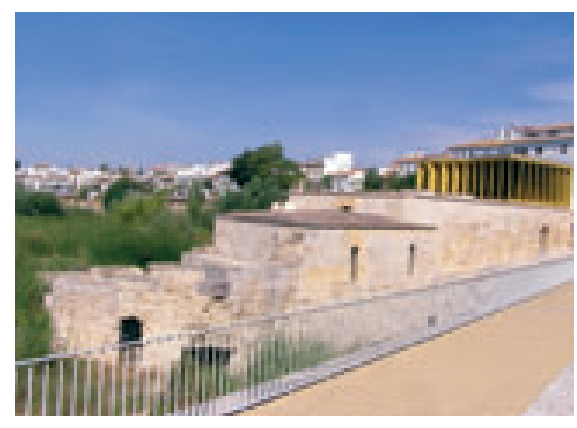

Vista exterior del Molino de Martos. Foto: Ángel Montero

el campanario de la Mezquita-Catedral al fondo. En esta parte de la ribera colmatada de sedimentos y llena de vegetación se puede observar una gran cantidad de avifauna procedente de los Sotos de la Albolafia, Monumento Natural cercano de 21,36 hectáreas, claro ejemplo de humedal fluvial con 115 especies de aves censadas y algunas de ellas con colonias de varios miles de ejemplares.

En la planta baja del Molino, es visitable la sala de molienda con una impresionante bóveda de cañón con lucernarios, que se ven en el suelo de la sala de exposición. De las diez estructuras de molienda originales sobre los pozuelos quedan algunas ruedas de moler inferiores o soleras, fabricadas en piedra caliza traida de la zona de Cabra-Carcabuey, en la Sierra Subbética cordobesa. Este origen fue descubierto tanto por el tipo de roca, caliza nodulosa, como por algunos fósiles característicos que contienen, como son algunos fragmentos de moldes internos de ammonites, moluscos marinos de hace unos 150 millones de años (Jurásico) (MONTERO, 2008).

También es visitable la zona de antiguos batanes, aunque está tan transformada que no quedan señales de su antigua actividad.

\section{CONCLUSIONES}

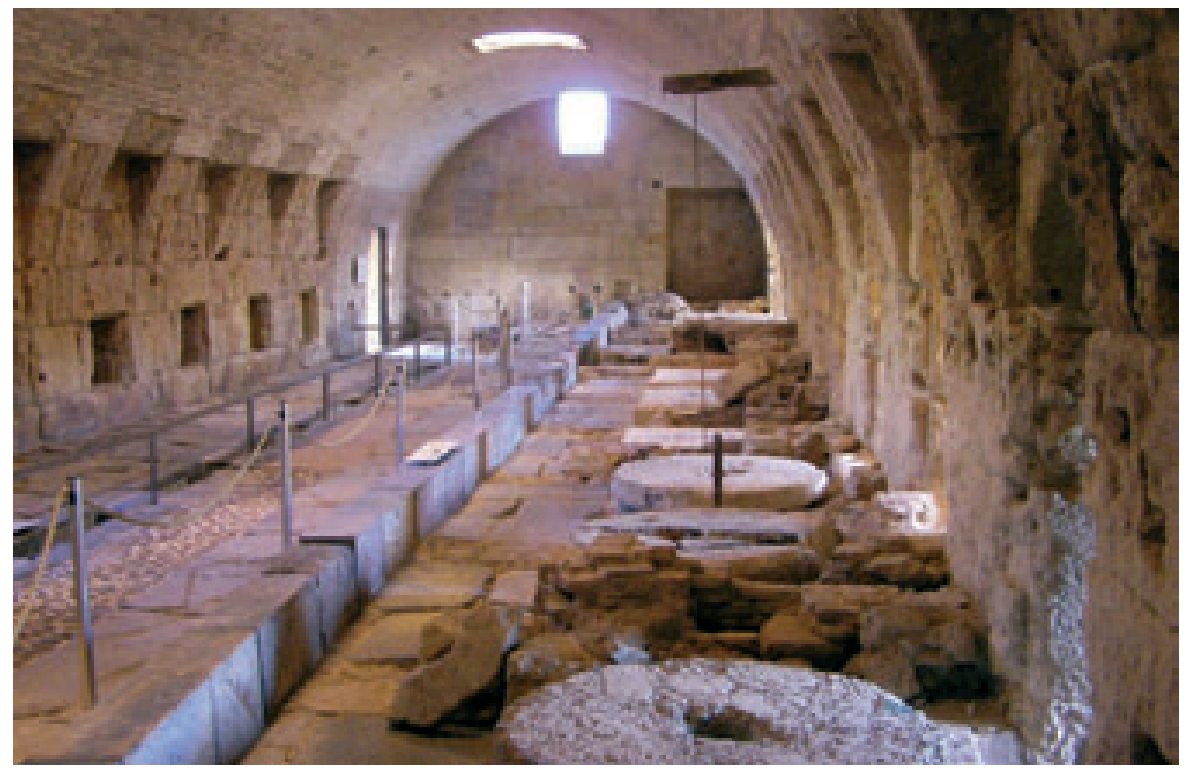

La inauguración en Córdoba del Museo Hidráulico o Museo del Agua supuso para la ciudad:

1.- La recuperación y puesta en valor de un elemento del patrimonio arquitectónico e histórico cordobés: un Molino de agua de origen medieval.

2.- La apertura de un nuevo Museo, que ampliaba la oferta cultural de la ciudad, con una exposición sobre la actividad industrial que tuvieron los molinos del Guadalquivir a lo largo de los siglos.

3.- Un nuevo impulso en la paulatina recuperación de las riberas del Guadalquivir a su paso por la ciudad como parte de un Plan Especial de Rehabilitación del Río puesto en marcha por el Ayuntamiento de Córdoba.

\section{Ángel Montero}

IMGEMA - Jardín Botánico de Córdoba 


\section{Datos de base de la vega del Guadalquivir}

La información de carácter patrimonial contenida en el Sistema de Información para la Gestión Integral del Patrimonio Cultural, relativa a la vega del Guadalquivir, se analizará en base al patrimonio inmueble que se haya localizado cartográficamente en la misma.

Esta zona comprende términos municipales incompletos pertenecientes a las provincias de Córdoba, Jaén y Sevilla. Los términos municipales afectados son los siguientes: en la provincia de Córdoba: Adamúz, Almodovar del Río, El Carpio, Córdoba, Fuente Palmera, Hornachuelos, Montoro, Palma del Río, Pedro Abad, Posadas, Villa del Río y Villafranca de Córdoba. Todos ellos incompletos menos Palma del Río. En la provincia de Jaén: Andújar, Espelúy, Lopera, Marmolejo y Villanueva de la Reina. Todos incompletos menos Espelúy. En la provincia de Sevilla: Alcolea del Río, Brenes, Cantillana, Carmona; Écija, Lora del Río, Peñaflor, Tocina, Villanueva del Río y Minas y Villaverde del Río. Todos ellos incompletos menos Bre- nes y Tocina. Se han localizado 937 inmuebles; 503 en Córdoba, 179 en Jaén y 255 en Sevilla.

De estos inmuebles el 90\% corresponden a sitios arqueológicos, debido a que ya desde el Paleolítico comienzan a localizarse asentamientos junto a las márgenes del río, aunque es en Época romana cuando se observa la mayor cantidad de sitios. La gran fertilidad del suelo de la vega, traerá como consecuencia la explotación agrícola y una gran producción de vino, aceite y cereales que se exportan a Roma y otras zonas del Imperio, lo que explica la gran cantidad de villae y alfares romanos que se encuentran en este territorio. Entre los sitios arqueológicos mas destacados de la vega están el Llanete de los Moros, Celti, Cercadilla o Madinat Al -Zahara.

En cuanto al patrimonio arquitectónico, la mayor cantidad de inmuebles localizados corresponden a Córdoba, especialmente a su centro histórico que contiene gran cantidad de inmuebles protegidos.
Entre estos inmuebles destacan un gran número de iglesias y palacios como el Palacio de Viana, la Iglesia de Regina o los puentes sobre el río en toda la vega.

El patrimonio etnológico se ve reflejado en la vega a través de cortijos, haciendas, alfares y molinos, ya que en la época actual se continúa con la actividad agropecuaria y de transformación en la zona.

Desde el punto de vista de las tipologias funcionales y periodos históricos a los que se asocia el patrimonio inmueble de la zona se han utilizado los términos del Tesauro de Patrimonio Histórico agrupándolos de la siguiente manera, ya sea patrimonio arqueológico, arquitectónico o etnológico:

- Edificaciones productivas que contienen las siguientes tipologías: edificios industriales, agropecuarios, ganaderos, complejos extractivos, comerciales, de hosteleria, almacenes, minas y locales comerciales. Los inmuebles pertenecientes a esta tipología suponen un $37 \%$ del total.
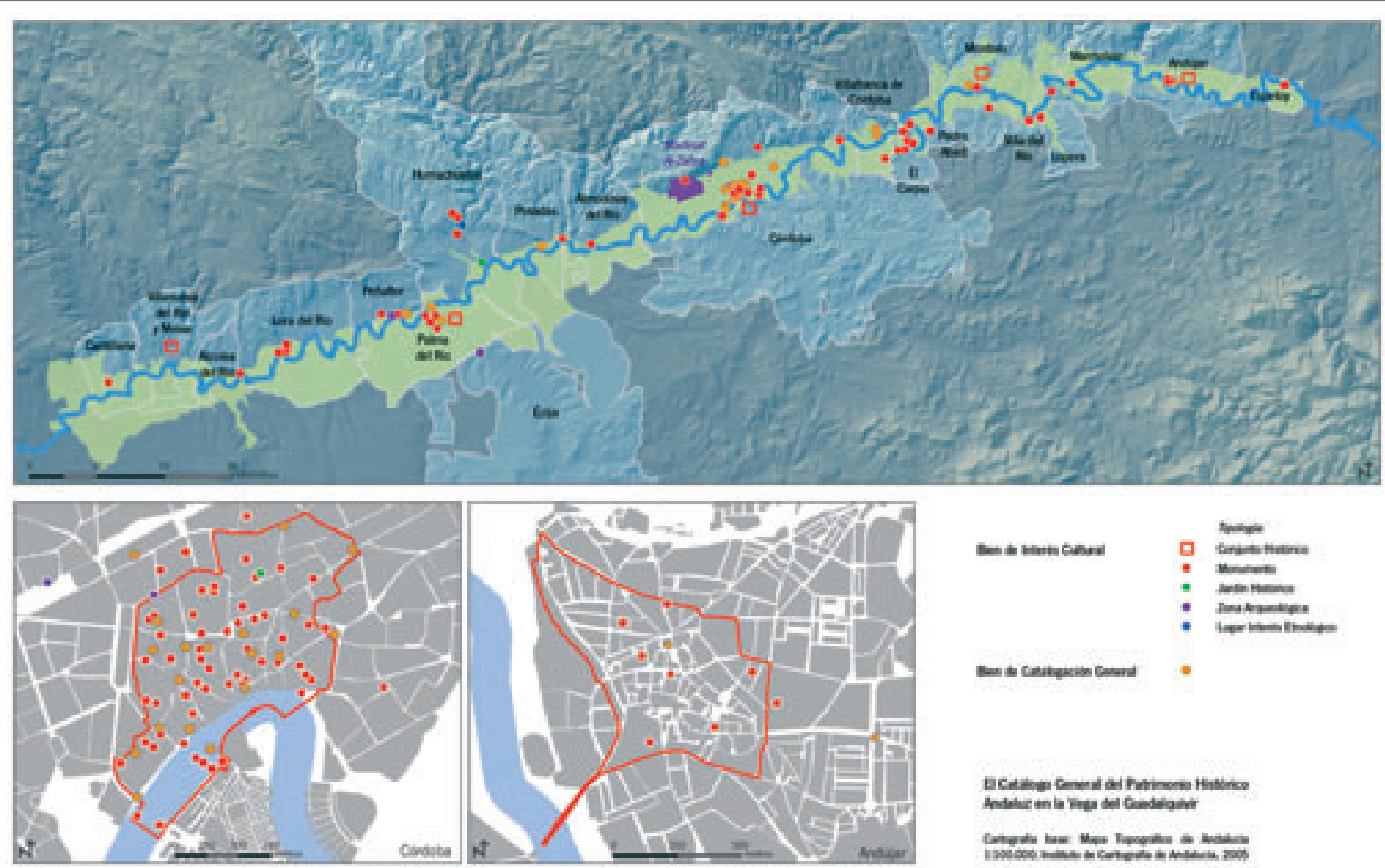

Catálogo General de Patrimonio Histórico Andaluz

La Ley 14/2007 de 26 de noviembre, de Patrimonio Catalogación General y los incluidos en el Inventario Histórico de Andalucia concibe el Catálogo General General de Bienes Muebles del Patrimonio Histórico del Patrimonio Histórico Andaluz, como instrumento Español.

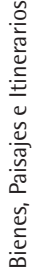
fundamental para la tutela y conocimiento de los bienes en él inscritos. El Catálogo, según el artículo 7, punto 1 de esta Ley, comprende tres categorías de bienes, los Bienes de Interés Cultural, los bienes de
En el plano de la demarcación de la vega del Guadalquivir, hemos localizado un total de 153 inmuebles protegidos, de los cuales 120 son Bienes de Interés Cultural y 33 son de Catalogación General.

Alfonso Montejo Ráez, Olga Viñuales Meléndez Servicio de Protección del Patrimonio Histórico Dirección General de Bienes Culturales 


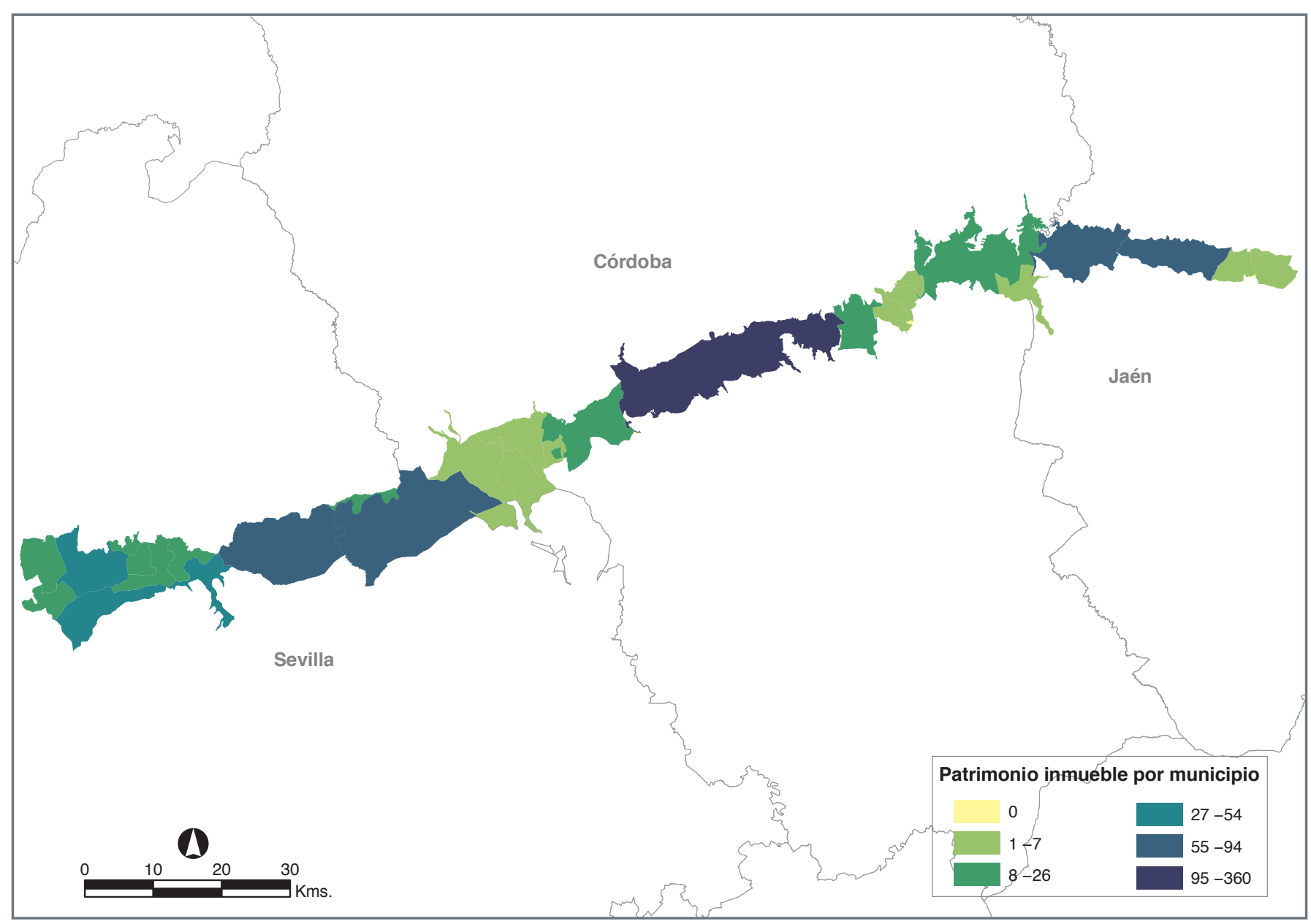

Tipologías Funcionales

Periodos Históricos
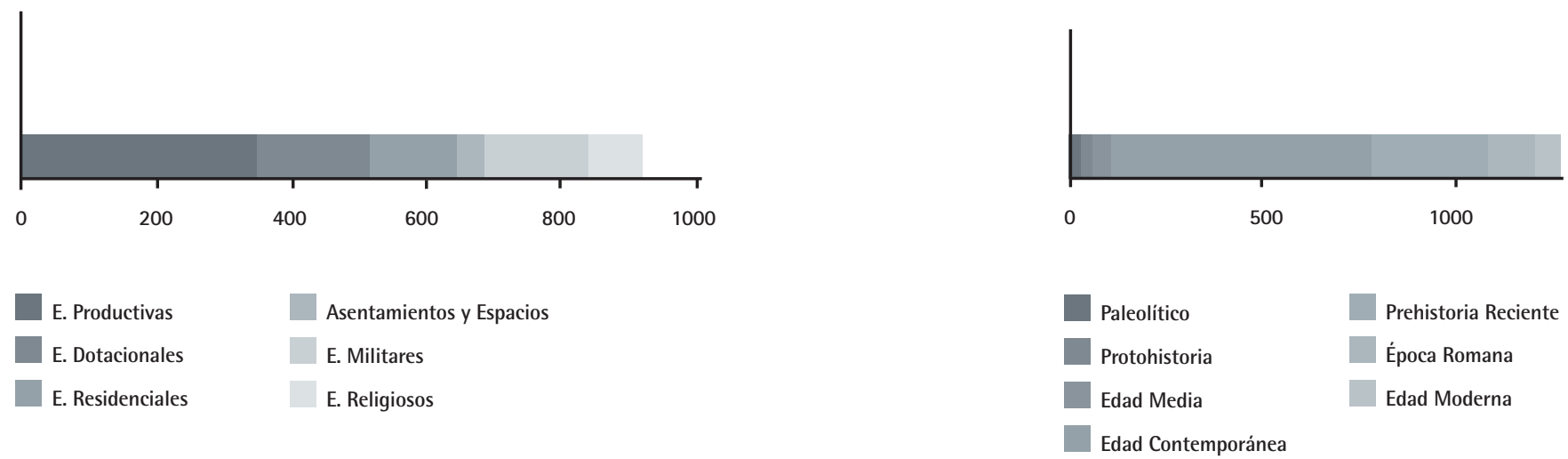

- Edificaciones dotacionales que engloban las siguientes tipologías: edificios administrativos, asistenciales, de comunicación, de espectáculo, de exposiciones, de transporte, baños públicos y depósitos documentales. Los inmuebles pertenecientes a esta tipología suponen un $14 \%$ del total.

- Espacios libres que agrupan: asentamientos, espacios rurales, espacios urbanos y zonas verdes. Los inmuebles pertenecientes a esta tipología suponen un $20 \%$ del total.

- Edificaciones militares que abarcan: fortificaciones y torres defensivas Las entidades pertenecientes a esta tipología suponen un $4 \%$ del total.
- Edificaciones religiosas. Los inmuebles pertenecientes a esta tipología suponen un $8 \%$ del total.

- Edificaciones residenciales que comprenden: viviendas, casas y palacios. Los inmuebles pertenecientes a esta tipología suponen un 17\% del total.

Esta distribución tipológica parece bastante equilibrada, siendo mayoritarios los edificios productivos y los asentamientos que suponen entre ambos un 57\% del total. Les siguen los edificios dotacionales y después los residenciales y los religiosos, siendo los últimos los militares. Ello se debe como ya hemos dicho a que el patrimonio arqueológico cuenta con más del doble de inmuebles registrados que las otras dos caracterizaciones juntas, por lo que sus tipologias marcan la pauta general.

En cuanto a los periodos históricos, el que más destaca es la Época Romana, con 671 entidades patrimoniales, con una cantidad intermedia tenemos la Edad Media con 299 inmuebles y los que menos contienen son la Edad Contemporánea con 57 y la Prehistoria Reciente con 25.

Pilar Mondéjar Fernández de Quincoces Salud Soro Cañas

Centro de Documentación y Estudios del IAPH 




政

- 1 Presa y central del Jándula (1927)

- 2 Presa y central de Encinarejo (1928)

- 3 Pueblo de colonización de Llanos del Sotillo (1956)

- 4 Pueblo de colonización de Maruanas (1964)

- 5 Presa y central de El Carpio (1925)

- 6 Silo de almacenamiento de la fábrica de Pastas Gallo

- 7 Pueblo de colonización de San Antonio (1960)

- 8 Escuela Nacional de niñas (1933)
- 9 Escuela Nacional de niños (1928)

- 10 Fábrica de cervezas "El Águila" (1962)

- 11 Pueblo de colonización de Encinarejo (1942)

- 12 Pueblo de colonización de Rivero de Posadas (1953)

- 13 Fábrica de harinas y tejidos de yute Sánchez Pastor (1926)

- 14 Fábrica azucarera San Fernando y destilería Los Rosales (1925)

- 15 Pueblo de Colonización de Esquivel (1952-1955)

- 16 Presa y central de Alcalá del Río (1928) 


\section{Elefantes de vapor. El patrimonio de la modernidad y su dimensión territorial en el valle del Guadalquivir}

Plácido González Martínez,

Marta Santofimia Albiñana, Centro

de Documentación y Estudios del IAPH
Durante su estancia en Holanda, desde 1629 a 1649, René Descartes pudo conocer y admirar de primera mano la labor de constructores de diques, que arrebatando terreno al mar, creaban un nuevo territorio, fértil y productivo, ofreciendo un ejemplo temprano de la fascinación por la tabula rasa como referente constante de la modernidad desde el siglo XVII hasta nuestros días. Como mostraría en su Discurso del método (1637), la Razón, atrincherada tras las barreras artificiales que la cultura y la ciencia habian erigido a lo largo de la historia, podia hacer frente a la naturaleza, someterla y utilizarla para construir un nuevo mundo.

Las referencias que proporcionaban los Países Bajos como territorio artificial presentaban a la tabula rasa no como un proceso destructivo sino como acto creativo de primer orden, por el cual la relación entre técnica y naturaleza, lejos de pensarse en términos de oposición, se planteaba desde la complementariedad y la mejora mutua. Es por ello que a inicios del siglo XX, el dominio y control de la fuerza del agua cobraran un especial significado a ojos de los arquitectos de la modernidad, que fascinados por la capacidad de transformación de la ingeniería, siguieron mirando hacia Holanda, concretamente a la obra hidráulica de mayor envergadura que se emprendia en Europa en aquellos momentos: la desecación del Zuidersee, iniciada en 1927 con la construcción de un dique de treinta y dos kilómetros de longitud, como primer paso para la desecación del estuario al que se asomaba la ciudad de Amsterdam para su posterior conversión en tierras cultivables y urbanizables.

El perfeccionamiento de la naturaleza no se detenía en el propósito de la creación de espacio vital para la cultura, sino que, como ocurrió en los Estados Unidos a partir de 1933 con la creación de la Tennessee Valley Authority (TVA), iba más allá, apostando por transformar la economía agrícola a través de la racionalización de los riegos y la creación de una red de canalizaciones que, a modo de segunda naturaleza superpuesta sobre el territorio, racionalizase una actividad tradicionalmente expuesta a la ávida sobreexplotación humana y a los vaivenes caprichosos del clima.
Si bien el control y la racionalización del agua ya habían sido puestos en práctica por la estrategia civilizadora de Roma más de dos milenios antes, el proyecto moderno para la transformación del territorio rural presenta además la particularidad de la producción de energía. Antes incluso que la TVA, las autoridades de la recién fundada Unión Soviética localizaron en ésta un campo de actuación preferente cuyas líneas rectoras quedaron delineadas con la redacción del plan GOELRO (1920) para la electrificación de Rusia. Preveian así la construcción de diez grandes plantas hidroeléctricas que suministrasen la energía suficiente para orquestar la deseada disolución de la ciudad en el campo que imaginaron con brillantez los arquitectos desurbanistas y que impulsó algunas de las investigaciones urbanísticas más interesantes y atrevidas que vieron el siglo pasado.

De manera intencionada, el recorrido por el primer tercio de siglo a través de Holanda, los Estados Unidos y la Unión Soviética, ilustra la suma de los propósitos del control del agua, la mejora de la agricultura y la producción de energía, sirviéndonos la posibilidad de leer un propósito de modernización territorial de indiscutible valor patrimonial contemporáneo, indiferente a la dispersión geográfica y al diferente sesgo politico de sus promotores. A través de la siguiente ruta habremos de mostrarlo como espíritu de los tiempos a nivel global cuya manifestación en el valle del Guadalquivir resulta tan ejemplar como reveladora.

En el caso de España, la experiencia fue resultado de una gestación que comenzó en el siglo XIX cuando las propuestas sobre política hidráulica de Joaquín Costa trazaron las líneas generales de la modernización agraria e industrial del país. Tras la constitución de las Confederaciones Hidrográficas en 1926, el impulso político se dotó de las herramientas administrativas necesarias para emprender la planificación hidrológica, la gestión de los recursos acuiferos y la construcción de las infraestructuras, que por encima de vicisitudes políticas, continuaron a lo largo de la Segunda República y la dictadura franquista convirtiéndose en uno de los pilares del desarrollo económico y social del país. 

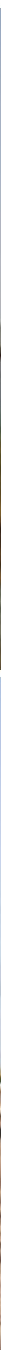

Escuela nacional de niños. Villafranca de Córdoba (1928)

Foto: Juan Carlos Cazalla, IAPH

Escuela nacional de niñas. Villafranca de Córdoba (1933).

Foto: Juan Carlos Cazalla, IAPH

Fábrica azucarera San Fernando y destilería Los Rosales. Tocina. (1925).

Foto: Juan Carlos Cazalla, IAPH

Fábrica de harinas y tejidos de yute Sánchez Pastor. Peñaflor (1926).

Foto: Juan Carlos Cazalla, IAPH

hubo de compatibilizarse con el escaso espacio disponible para su construcción, lo que determinó que se integrara la central en la pantalla de la presa a modo de prolongación del paramento en expresionistas formas. La presa, de tipo de gravedad, planta curva y sección triangular, cuenta con una altura de 90 metros sobre el cauce y una longitud de 200 metros. En su coronación se sitúa el torreón almenado que aloja las compuertas y que se abre a la cara aguas abajo con un balcón en ménsula, quedando el conjunto revestido de piedra con la clara intención de integrarlo en el entorno.

Aguas abajo encontramos el salto y la central de Encinarejo (1928), construidos para aprovechar el desnivel de 92 metros del río Jándula hasta su confluencia con el Guadalquivir. La central se adosa, al igual que en el caso anterior, a la pantalla de la presa que esta vez responde a la tipología de presa vertedero de 30 metros de altura. El edificio de turbinas, de planta rectangular, está desplazado hacia la margen derecha quedando el conjunto igualmente revestido con sillares de granito. Su construcción se inicia en 1928, aprovechando las infraestructuras que se estaban utilizando aguas arriba, y se pone en servicio a finales de 1930, cuatro meses después de la presa del Jándula.
Como parte de la estrategia de acumulación y distribución de agua que seguía la política hidráulica, la colonización del valle del Guadalquivir se basó en el trazado de una red de canales que servian de infraestructura base para el desarrollo de cultivos de regadío. Esta nueva actividad agricola requería de la construcción de nuevos pueblos, que eran objeto de una experiencia singular de adaptación de la arquitectura popular a los dictados de normalización que la modernidad imponía, y que constituyen por sí mismos un valor patrimonial de primer orden, manifestado de forma ejemplar en el pueblo de Llanos del Sotillo (1956), obra de los arquitectos José Antonio Corrales y Juan Ponce Bago.

Llanos del Sotillo se sitúa junto a la carretera nacional IV, afirmando su condición icónica con la torre de la iglesia como hito que señala el corazón del pueblo. Un espacio central que, en la más pura línea de las investigaciones desarrolladas por los CIAM a partir del VIII Congreso de Hoddesdon (1951), quedaba caracterizado por la construcción de una poderosa infraestructura social que Corrales resolvió con excepcional sencillez: un edificio lineal elevado sobre pilotis, que contenía las viviendas para los maestros, la escuela, y la iglesia, dejando un espacio público cubierto de excepcional belleza. Es de señalar el cuidado de Corrales por lo 
cívico, evidenciado en el sensible trazado de las calles peatonales, intimamente vinculadas al desarrollo de las viviendas, que se alzan sobre el espacio público creando una sutil celosía arquitectónica, espacio de luces y sombras y de intensa actividad comunitaria que constituye un logro urbanístico de excepcional calidad.

La continua demanda de energía de la industria cordobesa en el primer tercio del siglo XX fue el origen del salto y la central eléctrica de El Carpio (1925). Situados en un tramo del río de relativa pendiente, el conjunto aprovecha la entrada y la salida de un meandro para separar la presa y la central incorporando 6 metros de desnivel al salto. La presa dispone de dos estribos a ambas márgenes del río y cinco contrafuertes que soportan las seis compuertas móviles, y en su margen derecha se alza la torreta de control sobre un arco de herradura con alfiz en forma de puerta sobre el puente, quedando en su conjunto revestida de bloques de piedra. El edificio de la central, premiado con la medalla de oro en la Exposición Internacional de las Artes Decorativas de Paris en 1925, es de planta rectangular, destacando por su belleza el remate de la cubierta de la sala de turbinas, compuesto por cúpulas sasánidas. Como ingenioso remate, aparece la cabeza de un elefante como ménsula del balcón que se asoma aguas abajo que, en palabras de Fernández-Shaw, "simbolizaria la energía de los 10000 caballos de fuerza de la Central, una nueva medida de fuerza electromotriz sería el elefante de vapor", y que sirve de muestra de la frescura ecléctica del arquitecto.

Tras la central del Carpio, el río endereza su curso, apuntando hacia la población de Villafranca de Córdoba, que sirve dos piezas de arquitectura del racionalismo de excepcional calidad, fruto de los programas de equipamiento social de la dictadura de Primo de Rivera. Situada en el corazón del pueblo, la Escuela Nacional de Niños (1928), proyectada por José Joaquín González Edo, constituye un manifiesto de modernidad; evidenciando la sencillez de la disposición de las aulas que reciben iluminación natural a través de los generosos huecos horizontales en contraste con el volumen vertical de la torre de ladrillo, hito urbano fácilmente reconocible desde la calle Alcolea a la que se abre.

De mayor pureza compositiva, la Escuela Nacional de Niñas (1929); construida por el mismo González Edo sólo un año después de la Escuela de Niños, aprovecha la libertad que le confiere una posición periférica menos comprometida, que permite ofrecer respuestas enormemente diversas a los condicionantes del programa. Sin renunciar a marcar igual que en la Escuela de Niños la verticalidad de la caja de escaleras, la Escuela de Niñas incide en la horizontalidad compositiva: desde las fenêtres a longeur de las fachadas principales, hasta la detallista introducción de las franjas corridas de ladrillo que interrumpen la blancura de los muros enfoscados, la vinculación del edificio al paisaje está marcada por el apego a la tierra y su condición de mirador hacia el valle.

Siguiendo aguas abajo el curso del río, la presencia de la obra de colonización franquista se marca con las presencias puntua- les de otros pueblos, como Maruanas (1964), San Antonio (1960), Encinarejo (1942) y Rivero de Posadas (1953), obras de Francisco Giménez de la Cruz, que debido a la proximidad de la capital cordobesa y a la intensa presión urbanistica reciente, han visto transformado su carácter de manera más o menos acusada al de residencias dormitorio o segundas residencias.

Es necesario, en este punto, hacer mención a cómo la concentración de actividad económica en Córdoba condujo a la instalación de establecimientos industriales que, en su relación con la agricultura, también son muestra de la complejidad y transversalidad de su transformación. En el recorrido de la carretera nacional hacia el suroeste, son fácilmente distinguibles las siluetas de los silos de almacenamiento de la fábrica de pastas Gallo (década de los 60), que tuvo sus orígenes en una instalación harinera que aprovechaba la fuerza del río para garantizar su suministro energético, y que a lo largo de cuatro décadas de crecimiento ha consolidado su presencia como polígono industrial de notable envergadura.

Idéntica notoriedad vertical cobran, en la aproximación a la capital en la antigua carretera nacional, los silos de hormigón de la fábrica de cervezas El Águila (Rafael de la Hoz Arderius y Gerardo Olivares James, 1962), que en su desplazamiento relativo ofrecen una inusitada ligereza al material. Haciendo las veces de reclamo publicitario, adquieren escala territorial en su contraposición suprematista a la estructura horizontal y pragmática de las naves de producción que buscan de manera sorprendente referencias en la extensión de la cercana mezquita catedral para ofrecer claves de posteriores cambios de uso, ampliaciones y modificaciones ligadas al avance de los procesos productivos.

El Águila responde a un tipo de establecimiento industrial que, en la más canónica tendencia de la modernidad, buscaba su asociación a la ciudad; de manera diferente a otros casos, relativamente frecuentes en la primera industrialización de Andalucia, como la fábrica azucarera San Fernando y destilería Los Rosales (1925), en la que la instalación de la industria supuso el origen de una nueva población, los Rosales, prácticamente independiente del núcleo existente de Tocina. Este hecho nos habla por si solo de la escala sublime de este establecimiento, hoy día abandonado y bajo amenaza de desaparición, que en su día constituyó un modelo fabril modélico, cuya inserción está completamente determinada por el territorio: la cercanía del curso del Guadalquivir proporcionaba el agua necesaria para el cultivo y el lavado de la remolacha; las canteras de piedra caliza próximas garantizaban el suministro de cal necesario para los procesos químicos, mientras que la conexión al ferrocarril permitía, diariamente, la entrada de hasta dos mil toneladas de remolacha y la salida de doscientos hectolitros de alcohol conseguidos a través del sistema Barbet.

También la vinculación al territorio es clave para explicar la situación y funcionamiento de la fábrica de harinas y tejidos de yute Sánchez Pastor (1926), en la localidad de Peñaflor, donde se evidencia su lógica de funcionamiento desde el cuerpo más próxi- 



Pueblo de colonización Esquivel (1952). Alcalá del Río, Sevilla. Pueblo de colonización Llanos del Sotillo (1956). Andújar, Jaén.

Fotos: Juan Carlos Cazalla, IAPH

Esquivel en fiestas.

Interior de la iglesia del poblado de Llanos del Sotillo.

Fotos: Juan Carlos Cazalla, IAPH

mo al rí, con la turbina y la bomba del transportador neumático del trigo, al cuerpo intermedio donde se situaban la maquinaria de producción de sémola, harina y derivados, hasta el cuerpo de entrada, que situaba a los almacenes, silos y oficina en inmediata proximidad a la línea de ferrocarril. La fábrica, en estado de abandono, evidencia la racionalidad de su funcionamiento además en la aplicación de tecnologías constructivas avanzadas para la época, como el hormigón armado.

Llegando al término de la ruta, la presencia de Esquivel (19521955), obra del arquitecto Alejandro de la Sota, constituye siempre una referencia sobre los invariantes, aciertos y paradojas de la arquitectura de colonización. Situado junto a la carretera de Villaverde a Alcalá del Río, la disposición radial de su trazado, el protagonismo y especial cuidado de los espacios y edificios públicos que se abren a la carretera, siguen ofreciendo testimonio de la difícil supervivencia de esta arquitectura al paso del tiempo. No obstante, la brillantez del proyecto sigue siendo evidente, a pesar de las transformaciones recientes de viviendas y mobiliario públi$\mathrm{co}$, y reafirma la condición de hito en la colonización, simétrico en nuestro recorrido a Llanos del Sotillo.

El ambicioso proyecto de hacer navegable el Guadalquivir tenía como último salto la presa y central de Alcalá del Río (1928). A diferencia del caso del Carpio, la central forma parte del cuerpo de la presa y se sitúa en la margen derecha del río. La presa, de ocho compuertas móviles sobre pilones separados 15 metros, reinterpreta el racionalismo más austero a través del recurso historicista que hemos señalado en las obras de Fernández Shaw, en este caso, al igual que en el Jándula, a través de la tipología de castillo medieval. Claro ejemplo del uso de este recurso es el artificio del azulejo azul entre los merlones del pretil de la central que pretende evitar la visión de la cubierta a dos aguas de la sala de máquinas.

Al final de esta lectura compleja, podremos entender que el patrimonio que la modernidad lega al campo está constituido por estas muestras de perfeccionamiento, progreso y mejora: presas, poblados, industrias y escuelas que llegan a través de la técnica. Y visto a través de los ojos color turquesa del elefante de vapor de El Carpio, se mostrará no como producto exclusivo de la razón, sino como sueño hecho realidad por la experiencia y la sensibilidad humana. 
AGUILÓ, M. (2002) La enjundia de las presas. Madrid: ACS., 2002, p. 113

ALBERICH, J. (1976) Del Támesis al Guadalquivir. Antología de viajeros ingleses en la Sevilla del siglo XIX. Sevilla: Universidad, 1976

AA.W. (1985) La imagen romántica del legado andalusi. Barcelona: Lunwerg /El Legado Andalusi, 1985

BÉCQUER, G. A. (2004) Obras completas. Madrid: Cátedra, 2004

BORROW, G. (1970) La Biblia en España. Madrid: Alianza, 1970

CALVO, F. et ál. (1991) Iconografía de Sevilla 17901868. Madrid: Ediciones El Viso, 1991

CÓRDOBA DE LA LLAVE, R.; HERNÁNDEZ IÑIGO, P.; ORTIZ MUÑOZ, J. (2005) Estudio sobre la propiedad y evolución arquitectónica de los molinos hidráulicos del Guadalquivir en la ciudad de Córdoba durante los siglos XIX y XX. Informe interno

COSANO, F. (1999) Iconografía de Córdoba. Córdoba: Cajasur, 1999

DAVILLIER, Ch.; DORÉ, G. (1988) Viaje por España (2 vols.). Madrid: Ediciones Grech, 1988

FERNÁNDEZ CASADO, c. (1981) Historia de los puentes en España. Puentes romanos. 1981, sp.

FERNÁNDEZ TROYANO, L. El patrimonio histórico de las obras públicas y su conservación: los puentes. Informes de la construcción, no 372 (1985), pp.11-28 *

FORD, R. (2008) Manual para viajeros por España y lectores en casa (7 vols.). Madrid: Turner, 2008

GAMIZ, A. (2008) Alhambra. Imágenes de ciudad y paisaje (hasta 1800). Granada: El Legado Andalusi, 2008

GIMÉNEZ CRUZ, A. (2002) La España pintoresca de David Roberts. El viaje y los grabados del pintor. Málaga: Universidad, 2002

KEAY, S.; CREIGHTON, J.; REMESAL RODRÍGUEZ, J. (2001) CELTI (Peñaflor). La Arqueología de una Ciudad Hispanorromana en la Baetica: Prospecciones y Excavaciones 1987-1992. Arqueologia Monografias. Consejería de Cultura, 2001
LACOMBA, J. F. (2002) La Escuela de Alcalá de Guadaira y el paisajismo sevillano 1800-1936. Sevilla: Diputación, 2002

LACOMBA, J. F. et ál. (2007) Los paisajes andaluces. Hitos y miradas en los siglos XIX y XX. Sevilla: Consejería de Obras Públicas y Transportes, 2007

LATOUR, A. de (2008) Estudios sobre España: Sevilla y Andalucía. Edición a cargo de Manuel Bruña. Sevilla: Ayuntamiento de Sevilla / ICAS, 2008

MÉNDEZ RODRíGUEZ, L. (2008) La imagen de Andalucía en el arte del siglo XIX. Sevilla: Centro de Estudios Andaluces, 2008

MONTERO, A.; CÓRDOBA DE LA LLAVE, R.; LORA, A. (2007) Los Molinos del Río Guadalquivir en Córdoba, de producir harina a producir cultura. Museo, 12 , pp. $17-24$

MONTERO, A. (2008) Origen de las piedras de moler en los molinos de Córdoba. En GARRIDO ARANDA, J. M.; MORENO PÉREZ M. F.; ROLDÁN CAÑAS, J. (Eds.) $6^{\circ}$ Congreso Internacional de Molinología. Córdoba: Servicio de Publicaciones. Universidad de Córdoba, 2007, pp. 161-174

NOVíSIMA Recopilación. Libro VII, título XXV, legajo II. En URIOL SALCEDO, J. Historia del transporte en España. Madrid: CIC. Turner, 1980, p. 92

PÁEZ BALACA, A. (1950) Cincuenta años de hormigón en España. R.O.P., 1950, p. 206

PAVÓN MALDONADO, B. (1990) Tratado de arquitectura hispano-musulmana. Madrid, 1990, p. 91

PONZ, A. (1988) Viaje de España. Tomos XIV-XVIII. Facsimil. Madrid: Ed. Aguilar Mayor, 1988 (1787), tomo XVI, carta sexta

PROYECTO de puente sobre el río Guadalquivir, Archivo General de la Administración, sección Obra Pública, caja 2123

El PUENTE de Triana. Archivo Municipal de Sevilla, informe del 30 de marzo de 1844

RAMÍREZ DE LAS CASAS DEZA, L. M. (1986) Corografía Histórico Estadistica de la Provincia de Córdoba. Facsímil. Córdoba, 1986 (1840), p. 115

RECONSTRUCCIÓN del Puente de Andujar, Archivo General de la Administración, sección Obra Pública, cajas 2340, 5743 y 5744
ROBERTSON, I. (1988) Los curiosos impertinentes. Madrid: Ediciones del Serbal / CSIC, 1988

RODRÍGUEZ BARBERÁN, F. J.... [et al.]. La Sevilla de Richard Ford, 1830-1833 : Centro Cultural El Monte, Sala Villasis, Sevilla, enero-marzo 2007 : catálogo de la exposición. [Sevilla] : Fundación El Monte, [2007]

RODINSON, M. (1989) La fascinación del Islam. Madrid: Júcar, 1989

RUBIATO LACAMBRA, J. (1997) Los puentes de Córdoba. La construcción de la urbe. Córdoba, 1997, p. 523

RUBIATO LACAMBRA, J. (2005) Los Puentes del Guadalquivir. Madrid: CIC., 2005, p. 30

SÁENZ, C. (1984) La fisiografía en la evolución de las comunicaciones. En Historia de las Obras Públicas. Real Academia de Ciencias Exactas Físicas y Naturales. Madrid, 1984, pp. 138-153

SANTIAGO PÁEZ, E. M.; CABRA LOREDO, M. D (1988) Iconografia de Sevilla 1400-1650. Madrid: Ediciones El Viso, 1988

SERRERA, J. M.; OLIVER, A.; PORTÚS, J. (1989) Iconografia de Sevilla 1650-1790. Madrid: Ediciones El Viso, 1989

VITRUVIO POLIÓN, M. L. (1995) Los diez libros de arquitectura. Madrid: Alianza Editorial, D.L. 1995, Libro III, Cap. IV 
ABAD CASAL, Lorenzo. El Guadalquivir : vía fluvial romana. Sevilla : Diputación Provincial,1975

CALZADA PÉREZ, Manuel. Pueblos de colonización [Recurso electrónico], I, Guadalquivir y cuenca mediterránea sur. Córdoba : Fundación Arquitectura Contemporánea,2006 *

CÓRDOBA DE LA LLAVE, Ricardo... [et al.]. Los molinos hidráulicos del Guadalquivir en la ciudad de Córdoba [Recurso electrónico] : estudio histórico y arquitectónico. Madrid : Ministerio de Fomento, CEDEX, CEHOPU, D.L. 2008, (Cuadernos de investigacion CEHOPU ; 3) *

CUENCA, Juan; DÍAZ, Guillermo; BERMÚDEZ, Pedro. Córdoba y el río Guadalquivir. Geometría, n 2(1986), p. 18-23

\section{GALINDO PÉREZ DE AZPILLAGA L.; MULERO} MENDIGORRI, A. El paisaje en la Vega media de Sevilla como elemento determinante en una nueva percepción de los espacios rurales. En: ¿Qué futuro para los espacios rurales? : XII Coloquio de geografía rural, 2004, León. León : Universidad de León, Departamento de Geografía, 2004, p. 557-567

GARCÍA MERCADAL, J. Viajes de extranjeros por España y Portugal : desde los tiempos más remotos hasta comienzos del siglo XX. V. 1. [Salamanca?] Junta de Castilla y León, Consejería de Educación y Cultura, 1999

GONZÁLEZ BARBERÁN, Vicente...[et al.]. Guadalquivires [cincuenta aniversario]. [Sevilla : Confederación Hidrográfica del Guadalquivir], [1977]

GONZÁLEZ LARA, José. Con el río Guadalquivir de la mano. [Sevilla] : Confederación Hidrográfica del Guadalquivir, D.L. 2002

GWYNNE, Paul. El Guadalquivir : su personalidad, sus gentes y su entorno. Sevilla : Renacimiento, 2006 *

JORNADAS DE HISTORIA SOBRE LA PROVINCIA DE SEVILLA (1. 2004. Villaverde del Río, CantiIlana y Alcálá del Río). Actas : la Vega del Guadalquivir. Sevilla : Asociación Provincial Sevillana de Cronistas e Investigadores Locales, D.L. 2004

JORNADAS DE HISTORIA SOBRE LA VEGA DEL GUADALQUIVIR ( ${ }^{\circ}$. 2005. Alcalá del Río Cantillana, Tocina y Villaverde del Río). Edad Contemporánea en la Vega : actas :II Jornadas de Historia sobre la Vega del Guadalquivir, Alcalá del
Rio, Cantillana, Tocina y Villaverde del Río 3, 4 y 5 de noviembre de 2005. Sevilla : Asociación Provincial Sevillana de Cronistas e Investigadores Locales, 2007

JUAN Navarro Baldeweg: rehabilitación del molino de Martos y Balcón del Guadalquivir : Córdoba : monográfico. Almería : Colegio de Arquitectos de Almería, 2004, (Documentos de arquitectura ; 56)

KEAY, Simon; CREIGHTON, John; REMESAL RODRÍGUEZ, José. Celti (Peñaflor) : la arqueología de una ciudad hispanorromana en la Baetica : prospecciones y excavaciones 1987-1992. Sevilla : Consejeria de Cultura, Empresa Pública de Gestión de Programas Culturales, 2001, (Arqueología. Monografias ; 12 *

LARREY HOYUELOS, Enrique. Actividades arqueológicas en el Bien de Interés Cultural Ciudad Romana de Celti (Peñaflor), Sevilla. En: Anuario Arqueológico de Andalucia. T.IIl: Actividades de Urgencia. Sevilla : Junta de Andalucia, Consejería de Cultura, 1990, T.III. Actividades de Urgencia, pp. $526-530$ *

LÓPEZ ONTIVEROS, Antonio. La imagen geográfica de Córdoba y su provincia en la literatura viajera de los siglos XVIII y XIX. Córdoba : Monte de Piedad y Caja de Ahorros de Córdoba, 1991

MORAL, Leandro del. La obra hidráulica en la cuenca baja del Guadalquivir (siglos XVIII-XX) : gestión del agua y organización del territorio. [Sevilla] : Universidad[etc.], D.L. 1991

NOËL, Edmundo. Las márgenes del Guadalquivir. Sevilla : [s.n.], 1870 Imp. José Ma Geofrín)

PALANCAR PENELLA, Mariano; PÉREZ FORTIS, Ma José; OLANO KRAUEL, Eduardo. Confederación hidrográfica del Guadalquivir :75 aniversario. [Sevilla] : Confederación Hidrográfica del Guadalquivir, D.L. 2002

PATRIMONIO histórico hidráulico de la cuenca del Guadalquivir.[Sevilla] : Confederación Hidrográfica del Guadalquivir, [2002] *

Los PUENTES sobre el Guadalquivir en Sevilla Sevilla : Colegio de Ingenieros de Caminos, Canales y Puertos, 1999 *

RECORRIDOS turísticos, culturales y ecológicos por las obras hidráulicas de las cuencas del Guadalquivir, Guadalete y Barbate. [Sevilla] :
Ministerio de Medio Ambiente, Confederación, Hidrográfica del Guadalquivir, D.L. 2003

REYES CANO, Rogelio. El río de Sevilla en la apreciación literaria (desde los textos grecolatinos a la generación del 27). Archivo Hispalense, nº 247 (1998), p. 91-114*

RíOS y ciudades europeas : espacios naturales, culturales y productivos = European cities and rivers : natural, cultural and productives spaces. Sevilla : Universidad de Sevilla, 2006 *

RUBIALES TORREJÓN, Javier (ed.). El Río Guadalquivir. Sevilla : Junta de Andalucia, Consejería de Obras Públicas y Transportes, 2008 *

RUBIATO LACAMBRA, Francisco Javier. Los puentes del Guadalquivir. Madrid : Colegio de Ingenieros de Caminos, Canales y Puertos, 2005, (Ciencias, humanidades e Ingeniería; 68)

SERRANO, D. La navegación del Guadalquivir entre Córdoba y Sevilla.- [Córdoba] : Imprenta del "Diario de Córdoba", 1913

SUÁREZ JAPÓN, Juan Manuel. Caminos y paisajes del bajo Guadalquivir. Sevilla : Turismo de la provincia de Sevilla, imp. 2002

URBANIZACIÓN de la ribera del estadio y rehabilitación del molino de Martos en Córdoba. Arquitectura, n³37 (2004), p. 4-10

La VEGA del Guadalquivir. Sevilla. El Correo de Andalucía, 2006

Nota: Bibliografia seleccionada por seleccionada por Isabel Guzmán (Biblioteca del IAPH). Para una mayor información puede consultar el catálogo online de la Biblioteca del IAPH (http://www.juntadeandalucia. es/cultura/iaph/absys/abwebp.exe/).

Las publicaciones marcadas con asterisco (*) se encuentran disponibles para su consulta en la Biblioteca del IAPH. El resto de las referencias se han localizado en diversas fuentes de información (REBIUN, DIALNET, base de datos del ISOC, CEHOPU, catálogo del IPCE) de ámbito nacional. 